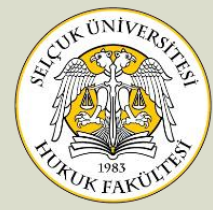

\title{
BİLİMSEL ETİK İHLALİ OLARAK İNTIHHAL KAVRAMI VE İLMÎ VE EDEBİ ESERLERDE INTIHAL SUÇU
}

\author{
Dr. Uğur ARSLAN *
}

Öz

Bir bilimsel eserin en önemli özelliklerinden birisi güvenilir olmasıdır. Güvenilirlik eserin güncel ve orijinal bir yapıda olması demektir. Oriji-nalliği sağlayacak olan eserin bilim dünyasına yeni bir şey katmış olması daha önce söylenmeyeni söylemiş olmasıdır. Eser sahibi çalışmasını yaparken elbette bazı kaynaklardan faydalanacaktır. Burada etik olan, yazarın yapmış olduğu iktibasları veya alıntıları usulünce göstermesi ve herhangi bir aşırmaya tenezzül etmemesidir. Günümüzde kaynaklara ulaşmak kolaylaşmış fakat "intihal" olarak isimlendirilen emek hırsızlıkları artmıştır. Özellikle akademideki rekabetçi yapı, unvan ve para kazanma hırsı ya da bilinçsizlik intihale neden olan başlıca etmenler arasında sayılmaktadır. Bu çalışmada ilim ve edebiyat eserlerindeki "intihal" kavramı ve FSEK'teki intihal suçları ele alınmıştır.

\section{Anahtar Kelimeler}

İntihal • Bilimsel Etik • İktibas • Eser • Fikir ve Sanat Eserleri Kanunu

\section{AS A SCIENTIFIC ETHICAL VIOLATION PLAGIARISM AND PLAGIARISM CRIME IN SCIENTIFIC AND LITERATURE WORKS}

\section{Abstract}

One of the most important features of a scientific work is its reliability. Reliability means that the work is up-to-date and original. The fact that the work that will provide originality has added something new to the world of science is that it has said what has not been said before. Of course, the author will benefit from some sources while doing his work. The ethical thing here is that the author duly cites

\footnotetext{
* Dr. Avukat, Ankara, Türkiye | Dr., Lawyer, Ankara, Turkey

凹 uarslantr@gmail.com • ORCID 0000-0002-3987-8465
}

Atıf Şekli | Cite As: ARSLAN Uğur, “Bilimsel Etik İhlali Olarak İntihal Kavramı Ve İlmî Ve Edebi Eserlerde İntihal Suçu", SÜHFD., C. 29, S. 2, 2021, s. 1557-1590.

Intihal | Plagiarism: Bu makale intihal programında taranmış ve en az iki hakem incelemesinden geçmiştir. I This article has been scanned via a plagiarism software and reviewed by at least two referees. 
quotations and does not bother with any plagiarism. Nowadays, it is easier to access resources, but labor theft called "plagiarism" has increased. Especially the competitive structure in the academy, the title and the ambition to earn money or unconsciousness are among the main factors causing plagiarism. In this study, the concept of plagiarism in science and literature works and plagiarism crimes in FSEK were examined.

\section{Key Words}

Plagiarism • Scientific Ethics • Quotation • Work • Law on Intellectual and Artistic Works

\section{I. İNTİHAL KAVRAMI}

\section{A. Gİiş}

Bilimsel çalışmaların gayesi bilinmezi bilinir hale getirmek, neden sonuç ilişkisini ortaya koyarak bir kuram ortaya koymak, evvelki bilimsel çalışmaların doğruluğunu test etmek, elde edilen bilgilerden bir senteze ulaşmaktır. ${ }^{1}$ Bilimsel çalışmalar sadece bilime değil; teknolojiye, ticarete, ekonomik gelişmeye, sanata hülasa birçok alana katkı sunmaktadır. Bu yüzden özgün-orijinal eserler ortaya koymak, bu çalışmaları teşvik etmek ve bunları ödüllendirmek önemlidir.

Türkiye Bilimler Akademisinin 2020 Türkiye Bilim Raporu'nda kişi başına düşen gayri safi yurt içi hasıla ile akademik yayınlar arasında doğrudan bir ilişki olduğu ifade edilmiştir. Gerçekten de bir ülke zenginleştikçe o ülkeye ait bilimsel çalışmaların da kalite ve kantite olarak, gelişmekte olan ülkelere oranla, ileride olduğu görülmektedir. ABD, Kanada Kuzey Avrupa ülkeleri ve Japonya Güney Kore böyledir. ${ }^{2}$

Eser sahibi ortaya bir eser koyarken orijinallikten uzaklaşır, hazıra kaçar, başkasının emeğini aşırırsa yeni bir eser ortaya koymamış olacak, bilim dünyasına herhangi bir katkıda bulunmamış olacaktır. Bu da bilimin yerinde sayması, hatta geri gitmesi, sonucunu doğurur. İnsanların ve toplumun bilime-bilim insanına güveni kaybolur.

1 ÖZENÇ UÇAK, Nazan / BİRİNCİ, Hatice Gülşen, “Bilimsel Etik ve İntihal”, Türk Kütüphaneciliği, S.22, 2008, s.187-204.

2 TÜBA, 2020 Türkiye Bilim Raporu, s.15, http://www.tuba.gov.tr/tr/yayinlar/suresizyayinlar/raporlar/turkiye-bilim-raporu, (E.T.:29.11.2020) 
Güvenilirlik bilimsel eserlerin en önemli özellikleri arasında belki de en başta gelenidir. Bu bakımdan eser sahibinin/yazarın eserindeki bilgilerin orijinal olması, özgün olması, kendi düşüncelerini kendine has üslupla yansıtması, faydalandığı kaynakları doğru ve usulüne uygun olarak eserinde göstermesi beklenir.

İntihal, Yükseköğretim Kurulu Bilimsel Araştırma ve Yayın Etiği Yönergesi'nin 8. maddesinde bilimsel araştırma ve yayın etiğine aykırı fiiller (çarpıtma, tekrar yayım, dilimleme ve haksız yazarlık ile birlikte) arasında gösterilmiştir. İntihal üniversite öğretim mesleğinden çıkartılma cezasını gerektirecek kadar ağır bir etik ihlalidir.

İntihalin neden olduğu en büyük sorunlardan birisi de bu haksız eylemin akademik saygınlığına gölge düşürmesi, haksız rekabete yol açması, bir bilim insanının güvenilirliğinin zedelenmesi, itibarının törpülenmesi ve erozyona uğramasıdır. Akademik dünyadaki rekabetçi yapı bilimsel bilginin kümülatif olarak ilerlemesinde katkı sunmakla beraber çeşitli emek hırsızlıklarına yol açtığı da göz ardı edilemeyecek bir gerçek olarak karşımızda durmaktadır. Öğrencisine kitap/makale yazdırıp üzerine kendi adını koymak, yabancı bir dildeki eseri tercüme edip kendi eseri imiş gibi yayımlatmak bilim çevrelerinde bir vakıa haline gelmiştir. İnternetin yaygınlaşması kopyala-yapıştır mantığını beraberinde getirmiş ve olumsuz anlamda da inanılmaz kolaylıklar sağlamıştır. Yeterli zamanı olmayan çeşitli idari görevleri bulunan akademik personel maalesef zaman baskısıyla intihale tevessül edebilmektedir. Bütün bu olaylara bir de ülkemizdeki akademik bilincin zayıf olması, farkındalığın olmayışı, mevzuatı bilmeme, teşvikler, para ödülleri, puanlar, yükselme, mevki kazanma hırsı ve saygınlık kazanma isteği gibi saikler de eklenince sorunun kök nedenleri ortaya çıkmış olmaktadır.

Türkiye' de 2007-2015 yılları arasında yazılmış 600 adet yüksek lisans ve doktora tezlerinden altı yüz adetinin örneklem olarak seçildiği bir araştırmada bahsedilen eserlerin benzerlik oranları \%28,7 olarak ortaya çıkmıştır. Bu oran vakıf üniversitelerinde yazılan tezler bakımından $\% 31,28^{\prime}$ dir. $^{3}$

TOPRAK, Ziya, “Türkiye' de Akademik Yazı: İntihal ve Özgünlük”, Boğaziçi Üniversitesi Ĕgitim Dergisi, C. 34 (2), 2017, s. 6, 7. 
Bilimsel çalışmalarda usulüne uygun olarak atıf yapma, kaynak gösterme bilimsel bilginin sorgulanması ve test edilmesi açısından önemli ve gerekli bir husustur. Nitekim Yargitay Hukuk Genel Kurulu bir kararında alıntı yapmanın faydalı bir mecburiyet olduğu fakat bunun yerleşmiş evrensel prosedürlerine uygun olarak yapılmasının elzem olduğunu ifade etmiştir. ${ }^{4}$

\section{B. INTIIHAL KAVRAMI}

İntihal kelimesi Arapça "nhl”" kökünden gelen intihạal (إنتحال) "kendine mal etme, benimseme" sözcügünden alıntıdır. Arapça nah!̣ (نحل) kelimesi ise "birine mal etme, bir eseri yanlış şaire atfetme" anlamında kullanılmaktadır. ${ }^{5}$ Türk Dil Kurumu (TDK) Sözlüğ̈̈'ne göre intihal "aşırmak" anlamına gelmektedir. ${ }^{6}$ Adalet Bakanlığı Hukuk Sözlüğü'nde de kelimenin TDK Sözlüğ̈̈'nde olduğu gibi tanımlandığını görülmektedir. ${ }^{7}$

Teknik ya da akademik anlamı olarak "aşırma" kelimesi Türkiye Bilimler Akademisinin Türkçe Bilim Terimleri Sözlügü̈nde “Bilimsel ya da sanatsal çalışmalarda, bir başkasının ürününün, görüşünün tümünü ya da bir

4 "Bir eserin yazılmasında, elbette kaynaklardan yararlanma olabilir. Hatta o eserin zenoinleştirilmesi, karşılaştırma yapılması bakımından zorunlu ve yarar da sağlayabilir. Böyle bir yöntem izlenirken, alınan düşünce ve örneğin kime ve hangi eserine ait bulunduğuna yollama yapılması yerleşmiş ve zorunlu bir yazım kuralıdır. Aksi halde, başkasına ait düşünce ve üretimleri kendinize aitmiş gibi bir sonuç çıkarılmış olur ki, bilim ve yazım kuralları bunu hoşgörü ile karşılamaz. Hatta düşüncesinden yararlanılan esere yollama yapılmakla (basım tarihi, yeri ve sayfa numarası gösterilmekle) okuyucunun gerektiğinde o eserden daha geniş biçimde yararlanma olanağını da sağlamış olur. Bu yöntem, bilim çevrelerince tartışılmaz ve yerleşmiş bir kuramdır. Özellikle bilimsel bir eserin yazılmasında bu kurala uymak ve bunu izlemek hukukun vazgeçemeyeceği bir sonuçtur." (Yargitay HGK, 10.5.2006, 2006/226 E., 2006/288 K.)

5 https://www.etimolojiturkce.com/arama/intihal, (E.T.:25.10.2020); İntihal kavram1nın İngilizce karşılığı olan "plagiarism" teriminin, kökeni Roma hukukundaki çocuk ve köle hırsızlığı anlamındaki "plagium" kavramına dayandığı belirtilmiştir. (DAVID, Lucas, in BUREN/DAVID (Hrsg.), Schweizerisches Immaterialgüter-und Wettbewerbsrecht I/3, Lexicon des Immaterialgüterrechts, Helbing und Lichtenhahn, Basel 2005, s.255'ten aktaran BELLICAN, Cüneyt, “Fikri Hukukta Manevi Haklar ve Manevi Hakların Korunması", Doktora Tezi İstanbul Kültür Üniversitesi Sosyal Bilimler Enstitüsü, 2008, s.479.)

6 Türk Dil Kurumu Sözlüğ̈̈, http://www.tdk.gov.tr/index.php?option=com_bts\&view=bts\&kategori1= veritbn\&kelimesec=24523, (E.T.:24.10.2020)

7 Adalet Bakanlığı Hukuk Sözlüğ̈̈, http://www.sozluk.adalet.gov.tr/intihal, (E.T.:20.01.2020) 
bölümünü kaynak göstermeden kullanma; bilim ve sanat alanında hırsızlık" şeklinde tanımlanmıştır. ${ }^{8}$

Yükseköğretim Kurumları Etik Davranış İlkeleri'nde intihal/aşırma (Plagiarism): "Bilimsel usullere uygun biçimde gerekli atıfları yapmadan ve kaynak göstermeden başkalarının fikir, veri, eser ve yayınlarını kendisine aitmiş gibi yayımlamak" 9 olarak tanımlanmıştır.

YÖK Bilimsel Araştırmalar ve Yayın Etiği Yönergesine göre ise intihal; "Başkalarının özgün fikirlerini, metotlarını, verilerini veya eserlerini bilimsel kurallara uygun biçimde atıf yapmadan kısmen veya tamamen kendi eseri gibi göstermek"tir. ${ }^{10}$ Yargıtay HGK ise intihali yukarıdaki tanımlara benzer biçimde tarif etmiştir. ${ }^{11}$

\section{C. İNTIHHAL TÜRLERI}

Doktrinde intihal türleri ve intihal olarak kabul edilen davranışlar genellikle aşağıdaki başlıklar altına toplanmaktadır:

- Klonlama: Eser sahibinin başkasının çalışmasını kendi eseri gibi sunmasi.

- Kopyalama: tek bir kaynaktaki metnin önemli bölümleri değişiklik yapmadan alma.

- Bulma-Değiştirme: Kaynağın önemli içeriğine dokunmadan kaynaktaki anahtar kelimeleri ve cümleleri değiştirerek kullanma.

- Remiks Yapma: Birçok kaynaktan alınan uyumlu ifadeleri kendi sözcükleriyle yineleme.

8 TÜBA Türkçe Bilim Terimleri Sözlüğü, http://www.tubaterim.gov.tr/, (E.T.:04.02.2019)

9 Yükseköğretim Kurumları Etik Davranış İlkeleri, https://www.ankara.edu.tr/wpcontent/uploads/sites/6/2015/01/etik-davran\%C4\%B1\%C5\%9F-ilkeleri.pdf, (E.T.:24.02.2019)

10 YÖK Bilimsel Araştırmalar ve Yayın Etiği Yönergesi, https://www.yok.gov.tr/Documents/Mevzuat/yuksekogretim_kurumlari_bilimsel_arastirma_ve_yayin_etigi_yonergesi.pdf, (E.T.:24.02.2019)

11 "5846 sayılı Fikir ve Sanat Eserleri Kanununda (FSEK) açıça tanımlanmamış olmakla birlikte sözlük anlamı itibariyle aşırma, başkasına ait eseri kendininmiş gibi gösterme, kaynak göstermeksizin başkasının eserinden parça alma ... anlamında olup, hukuk düzenince de bu anlam yüklenmiş ve yasaklanmıştır." (Yargıtay HGK, 29.01.2003, 2003/4-47 E., 2003/37 K.) 
- Geri Dönüştürme: Yazarın önceki kendi çalışmalarını kaynak göstermeden fazlaca kullanması. ${ }^{12}$

- Melezleme: Kaynak göstermeden kopyalanan metinler ile kaynağ1 gösterilen metinleri fark edilmeyecek şekilde birleştirme.

- Lapa Yapma: Kolayca fark edilmemesi için birçok kaynaktan kopyalanan materyali karıştırma.

- 404 Hatası Yapma: Olmayan kaynağı var gibi gösterme ya da kaynak hakkında hatalı bilgiler sunma.

- Toplama: Prosedüre uygun olarak kaynak gösterme fakat neredeyse hiç orijinal çalışma olmama.

- Yeniden Tweetleme: Prosedüre uygun olarak kaynak gösterme fakat orijinal metne çok fazla bağlı olma orijinal kaynaktan fazlaca alıntı yapma şeklindedir. ${ }^{13}$

12 Eser sahibinin işin kolayına kaçmak, alıntı sayısını ve skorunu üst seviyeye çıkarmak vs. gibi nedenlerle daha önce yayımlanmış olan kendi eserinden alıntı yapmasına literatürde "self plagiarism" denmektedir. Danıştay kararlarında anılan durum intihal olarak kabul edilmez ama kendinden aşırma "yanıltıcı, yanlış ya da eksik beyanda bulunma" şeklinde bir etik ihlaldir: "doktora tezinden alıntı yapılarak birden fazla makale üretildiği halde üretilen makalelerin kaynakçasında doktora tezinin gösterilmemiş olmasından ve de söz konusu yayınların lisansüstü tezlerden üretilmediği yönünde beyanname verdiği halde bu hususa uyup uymamasından kaynaklandığından uyuşmazlı̆̆ın çözümü için bilirkişi incelemesi yaptırlmasına gerek görülmeyerek, dava dosyasındaki jüri üyelerinin kişisel raporlar, etik alt komisyonu ve etik komisyonu raporlarmın birlikte değerlendirilmesi sonucunda; davacinın jüri üyeleri ve alt komisyon üyelerinin birbirini destekleyen tespitine göre doktora tezindeki kimi paragrafların değiştirilmeden makalelere aktarıldığı, buna karşılık söz konusu tezin kaynak olarak gösterilmeme davranışının doçentlik başvurusunda jüri üyelerini yanıltıcı, yanlış ya da eksik beyanda bulunmak şeklinde etik ihlali oluşturduğu sonucuna varıldığından ...davacının doçent unvanı alınabilmesi için doktora tezi dışında bir konuda özgün yeni bir araştırma yapma gerekliliğinden kurtulabilmek için doktora tezinin kaynakçalarda belirtilmeyerek sanki doktora çalışmasından başka bir konuda yeni bir araştırma yapılmış izleniminin yaratılmaya çalışıldığı hususlarına yer verilerek davacının etik ihlalinde bulunduğunun belirtilmesi..." (Danıştay 8. Dairesi, 26.09.2013, 2010/8937 E., 2013/6639 K.)

13 GÜCÜKOĞLU, Behlül/AYVAZ REİS, Zerrin, “Türkiye' de ve Dünyada İntihalin Yaptırımları", Akademik Bilişim, XVI. Akademik Bilişim Konferansı Bildirileri, Mersin, 2014, s.191.; Yükseköğretim Kurumları Etik Davranış İlkeleri, http://kurul.odu.edu.tr/files/akademik-etik-ilkeler.pdf, (E.T.:02.01.2019) 


\section{FSEK'E GÖRE İLMÎ VE EDEBÎ ESERLER}

FSEK madde 2 'de ilmi ve edebi eserler tanımlanmıştır. ${ }^{14}$ Maddeye göre yazılı eserler, bilgisayar programları, sahne eserleri, mimari projeler, teknik resimler, planlar, haritalar, coğrafi maketler vs. ilim ve edebiyat eseri olarak kabul edilmiştir. ${ }^{15} 16$

14 "I - İlim ve edebiyat eserleri:

Madde 2 - Illim ve edebiyat eserleri şunlardır:

1. (Değişik: 7/6/1995 - 4110/1 md.) Herhangi bir şekilde dil ve yazı ile ifade olunan eserler ve her biçim altında ifade edilen bilgisayar programları ve bir sonraki aşamada program sonucu doğurması koşuluyla bunların hazırlık tasarımları,

2. (Değişik: 1/11/1983 - 2936/1 md.) Her nevi rakıslar, yazılı koreografi eserleri, Pandomimalar ve buna benzer sözsüz sahne eserleri

3. (Değişik: 7/6/1995 - 4110/1 md.) Bedii vasfı bulunmayan her nevi teknik ve ilmi mahiyette fotoğraf eserleriyle, her nevi haritalar, planlar, projeler, krokiler, resimler, coğrafya ve topoğrafyaya ait maket ve benzerleri, herçeşit mimarlik ve şehircilik tasarım ve projeleri, mimari maketler, endüstri, çevre ve sahne tasarm ve projeleri.

(Ek: 7/6/1995 - 4110/1 md.) Arayüzüne temel oluşturan düşünce ve ilkeleri de içine almak üzere, bir bilgisayar programının herhangi bir ögesine temel oluşturan düşünce ve ilkeler eser sayılmazlar."

15 "Mahkemece benimsenen bilirkişi raporunda, dava konusu haber yazllarının hazırlık süreci ve sunum tarzı bakımından belirli bir üslubu olduğu ve FSEK 1/B anlamında hususiyet arzeden, ayn Kanun'un 2. maddesi kapsamında ilim ve edebiyat eseri olduğu mütalaa edilmiş ise de, uyuşmazlık konusu yazıların davacı yayın kuruluşunun haber servisi tarafından hazırlanan günlük olaylara yönelik haber yorumları niteliğinde oldukları tartışmasızdır. Haber niteliğinde hazırlanan yazların gazete okuyucusunun ilgisini çekecek tarzda ve habercilik mesleğine özgü haber diliyle yazllacağı, bu haliyle de genel anlamda yazılan açıklama ve ifadelerden farklı bir haber üslubuna sahip olacağı tabiidir. Esasen, habercilik mesleğinin genel prensipleri gereği bir olay hakkında edinilen bilgilerin ve düşüncelerin kamunun anlayabileceği biçimde doğru, kısa ve kolayca anlaşılabilir kılmak suretiyle haber diline dönüştürülmesi başlı başına 5846 sayılı FSEK 1/B maddesi anlamında hususiyet unsuru içeren ilim ve edebiyat eseri olarak kabulü sonucunu doğurmaz. Bu bakımdan, bilirkişilerden dava konusu haber yazılarının genel olarak habercilik mesleğinin gerektirdiği üslup ve sunum, bir başka deyişle gazetecilik gereği haber anlatımı, haber yazım kuralları ve haber dili dışında ayrıca 5846 sayılı FSEK 1/B maddesi anlamında haberi hazırlayan kişilerin de hususiyetini taşıyan, dolayısıyla FSEK 2. maddesi kapsamında ilim ve edebiyat eseri vasfı bulunan yazılar olup olmadığ $\mathrm{hu-}$ susunda değerlendirme içeren görüş alınıp sonucuna göre uyuşmazlığın hukuki nitelendirmesinin yapılması gerekirken, eksik inceleme sonucu yazlların eser olduğundan bahisle hüküm tesisi doğru görülmemiş, kararın bu nedenle bozulması gerekmiştir." (Yargıtay 11. HD, 2014/15492 E., 2015/42 K.)

16 Bahse konu madde edebi ve bilimsel eser mahiyetinde olmayan raks, pandomim gibi sahne eserlerinin bu kategoriye dahil edilmesi ayrıca üç bent halinde sayılan eserlerin aynı kategoriye sokulmasını icap ettirecek ortak bir yön taşımamaları ve başlığın içerikle uyuşmaması nedeniyle eleştirilmiştir. (EREL, Şafak, "İlim ve Edebiyat 


\section{E. İLGİLI MEVZUAT}

Ülkemizde kanun anlamında salt olarak intihal konusunu düzenleyen müstakil bir düzenleme bulunmamakla beraber çeşitli kanun ve yönetmeliklerde intihal konusunun dolaylı olarak düzenlenmiş olduğu görülmektedir. İntihal konusu daha çok bazı kurumların etik ile ilgili kendi mevzuatında ele alınmakta konunun cezai yönüne değil; idari ve etik boyutuna vurgu yapılmaktadır. Bu düzenlemelerde intihal yapan akademik personel hakkında kamu görevinden çıkarılmaya kadar varan çeşitli idari yaptırımlar söz konusu olabilmektedir.

Hukukumuzda intihali suç olarak düzenleyen tek kanun 5846 sayılı Fikir ve Sanat Eserleri Kanunu (FSEK)'dur. Bu Kanun dışında hukukumuzda intihale yer veren başlıca mevzuat ise şunlardır:

- 2547 Sayılı Yükseköğretim Kanunu,

- 15 Nisan 2018 tarihli Doçentlik Sınav Yönetmeliği,

- YÖK Bilimsel Araştırmalar ve Yayın Etiği Yönergesi,

- TÜBİTAK Araştırma ve Yayın Etiği Yönetmeliği,

- YÖK Öğrenci Disiplin Yönetmeliği.

\section{HUKUKUMUZDA İNTİHAL SUÇU}

\section{A. GENEL AÇIKLAMALAR}

Yukarıda belirttiğimiz gibi, hukukumuzda intihal kavramına ilişkin düzenlemeler bulunmaktadır. Fakat bu düzenlemelerin neredeyse tamamı konunun idari ve etik boyutuyla ilgilidir. İntihali gerçek anlamda ceza hukuku boyutuyla ele alan tek düzenleme 5846 sayılı Fikir ve Sanat Eserleri Kanunu'dur. ${ }^{17}$ Aslında bu Kanun, yasalaşmış olduğu 1951

Eserlerinde Çoğaltma ve Yayama Haklarının Kullanılması", İlim ve Edebiyat Eserlerinde Çoğaltma ve Yayama Haklarının İhlali ve Bunun Sonuçları Paneli, 1999, s.16) getirdiği fikri değerin ("geistesgut") haksız olarak sahiplenilmesi olduğu ifade edilmiştir. Alman mevzuatında da salt intihal suçunun yer aldığı hükümler bulunmamakla birlikte doktrin ve içtihatlarla kavramın yasal altyapısı oluşmuştur. Bu bağlamda Alman hukukunda bir kişinin kasten başkasının eser sahipliğinin inkârı ("anmaßung") olarak yorumlanabilecek her türlü mali hak ve manevi hak ihlali "intihal" olarak değerlendirilmiştir. (SCHRICKER/LOEWENHEIM, § 23, Kn.22'den aktaran BELLİCAN, s. 480.) 
yılında, bilim etiğinden ziyade, eser sahibinin ticari, maddi ve manevi haklarını korumak için yola çıkılmış ve hazırlanmış bir kanundur. ${ }^{18}$

Şüphesiz intihal fiili sadece ilim ve edebiyat dünyası ile sınırlı bir kavram değildir. Müzik ve sinema eserlerinde de intihal eylemleri irtikap olunabilmektedir. Çalışmamız sadece ilim ve edebiyat eserleri ile sınırlı olduğu için çalışmamızın konusu 5846 sayılı Fikir ve Sanat Eserleri Kanunu "Hukuk ve Ceza Davaları" başlıklı 5. Bölümü'nde, 5728 Sayılı Kanun ile değişik19 "Manevi Mali ve Bağlantılı Haklara Tecavüz" başlıklı 71.

18 "Meşrutiyet devrinin mahsulü olup, bundan 40 yıl önce hazırlanmış olan ve 8 Mayıs 1326 (1910) gününden beri yürürlükte bulunmuş olan Hakkı Telif Kanunu gerek şümul ve gerek ruh itibariyle tanzim edilmiş olduğu zamanın izlerini taşımaktadır. Şümul itibariyle kanun, tekniğin son 40 yıl içindeki umulmadık bir inkişafı neticesinde, kültür hayatı için son derece mühim önem kazanan filim ve radyoyu tabiatiyle hiç nazara almadığı gibi, işaret, resim ve ses nakline yarıyan âletler, hususiyle fotoğraf makinesi ve gramofon plâklarının yardımiyle yaptlabilen çoğaltma ve yayım imkânların da gereği gibi takdir etmemiştir. Ruh itibariyle kanun, o zaman hukuk sahasinda hâkim olan «sirf mamelek hakkl» nazariyesine dayanarak fikir eserlerini vücuda getirenlerin sırf maddi ve malî menfaatlerini korumakla uğraşmış, manevi menfaatlerini ise (ki buna frenkçe «droit moral» denir) kale almamıştır. Zikri geçen hususlardan sarfınazar, milletin fikir ve kültür hayatiyle çok yakından ilgili olan bu Telif Hakkı Kanunu, bundan 40 yal önceki Osmanl imparatorluğunun daha doğrusu o zaman fikir cereyanlarının merkezi olan istanbul'un fikrî durumuna az çok uyabilmiş ise de, memleketimizin son 25 yıl içindeki kültür ve hukuk inkılâpları neticesinde meydana gelmiş olan bugünkü millî fikir ve kültür hayatiyle modern mevzuatımıza asla tekabül etmemektedir Bu durumdan daha doğrusu bu uygunsuzluk ve kifayetsizlikten zarar gören, yalnız ilim, fikir ve sanat erbabı değil, bütün memleketin irfan hayatıdır. Çünkü milletin serveti demek olan vatandaşların ibda kabiliyeti, kolay para kazanmak hırsı ile hareket edenlerin istismar yollarına karşı kâfi derecede korunmadıkça ilim, fikir ve sanat adamlarımızdan memleketimizin muhtaç olduğu keyfiyet ve kemmiyette fikir mahsulleri, hele dünya çapında eserler beklenemez. Bu sebeplerden dolayı Telif Hakkı Kanununun değişstirilmesinin bir zaruret olduğu fikri yıllardan beri ilgilileri meşgul ederek 1938 yılında toplanmış olan Neşriyat Kongresinde açık ifadesini bulmuştur. Hem kongrenin çalışmalarından hem de son on yıl içinde bu sahaya taallûk eden ilm $\hat{\imath}$ yayımlardan faydalanılarak memleketimizin özel ihtiyaçlarına ve en modern yabancı kanunlarla milletlerarası andlaşmalara uygun gelen bu tasarı hazırlanmıştır." (TBMM Fikir ve Sanat Eserleri Hakkında Kanun Tasarısı ve Millî Eğitim ve Adalet komisyonları raporları, https:/www.tbmm.gov.tr/ tutanaklar/TUTANAK/TBMM/d09/c010/tbmm09 010010ss0289.pdf, (E.T.:07.01.2019))

19 "Kanunun mevcut metninde suçlar tanımlanırken, manevi haklara tecavüz ve malî haklara tecavüz ayırımı esas alınmıştır. Öncelikle belirtilmek gerekir ki, bu Kanunun koruma altına aldığı malî ve manevi haklara tecavüz fiilleri iç içe bir mahiyet taşımaktadır. Bir fiille, bir kişinin sadece manevi hakkı veya malî hakkı ya da bunların her ikisi de ihlal edilmiş olabilir. Korunan haktan hareketle ayn fiilin iki ayrı suç olarak nitelendirilmesi yoluna gidilmesi, ceza hukukundaki suç tanımlamalarında esas alınan suç politikası ilkeleriyle bağdaşmamaktadır...Yapılan değişiklikle, madde kapsamında çeşitli suç tanımlarına yer verilmiştir. Bütün 
maddesinde yer alan intihal suçlarından 2, 3 ve 5 bentlerde yer alan suçlarla sinırlandırılmıştır.

FSEK'e göre, intihal teşkil eden eylemler için ceza davası ile beraber (intihal fiili eser sahibinin manevî veya malî haklarına tecavüz teşkil ettiğinden) eser sahibinin uğradığı zararlar veyahut manevî veya malî haklarının ihlâli dolayısıyla tazminat davası (FSEK madde 70), tecavüzün men'i (FSEK madde 69) ve tecavüzün ref'i (FSEK madde 66 vd.) davaları ve eser sahipliğinin tespiti (FSEK madde 15/3) davası da açılabilir. ${ }^{20}$ Nitekim, intihal suçu ile fail eser sahibinin manevi ve malî haklarına tecavüz etmektedir. Anılan haklar mutlak haklar kategorisinde yer aldıklarından herkese karşı ileri sürülebilir ve herkes tarafından ihlal edilebilirler. Somut olayda herhangi bir hukuka uygunluk sebepleri mevcut değilse bu haklara yönelen tecavüz fiilinin varlığı, başlı başına hukuka aykırılık oluşturmaktadır. ${ }^{21}$

Benzer biçimde, mali hakları ihlal edilen eser sahibi, tecavüz edenin kusurlu olması halinde, FSEK madde 70/II uyarınca TBK'nın haksız fiillere ilişkin genel hükümleri çerçevesinde tazminat talep edebilir. Bu durumda TBK'nın haksız fiillere ilişkin hükümleri [haksız fiilin şartları (TBK m. 49), zarar ve tazminat miktarmm tayini (TBK m. 50, 51), tazminatın indirilmesi (TBK m. 52), müteselsil sorumluluk (TBK m. 61, 62) ve zamanaşımı (TBK m. 72)] kıyasen uygulanacaktır. ${ }^{22}$

bu tanımların ortak özelliğ $i$, suç oluşturan fiillerin bu Kanunda koruma altına alınan fikir ve sanat eserleriyle ilgili manevi ve malî haklar ihlal etmesidir. Maddenin (4) ve (5) numaral bentlerinde çeşitli intihal fiilleri bağımsız suçlar olarak tanımlanmıştır. (5) numaralı bentte bilimsel etik kurallarına aykırı olarak bir eserden kaynak göstermeksizin iktibasta bulunma fiili ceza yaptırımı altına alınmıştır." (5728 Sayılı Kanun madde 138 gerekçesi, TBMM Mevzuat Bilgi Sistemi, https://mevzuat.tbmm.gov.tr/mevzuat/faces/kanunmaddeleri?pkanunlarno=54956\&pkanunnurasi=5728,((E.T.:05.01.2019))

20 ŞAFAK N. Erel, Türk Fikir ve Sanat Hukuku, 3. Bası, Yetkin Yayınları, Ankara, 2009, s. 345; TEKİNALP, Ünal, Fikri Mülkiyet Hukuku, Vedat Kitapçllı, İstanbul, 2012, s. 303.

21 YILMAZTEKIN, Hasan Kadir, “Fikir ve Sanat Eserleri Kanunu Uyarınca Eser Sahipliği ve Hak Sahipliği ile Bunların Tecavüz Davaları Bağlamında Davacı Sıfatına Etkileri", Adalet Dergisi, 2020/2 Sayı 65, s. 502; YAVUZ, Levent/ALICA, Türkay/MERDİVAN, Fethi, Fikir ve Sanat Eserleri Kanunu Yorumu, Cilt II, Seçkin Yayınevi, 2. Bask1, Ankara, 2014, s. 1881.

22 YAVUZ/ALICA/MERDIVAN, s. 2213. 
Somut olayda intihal fiilinin varlığı hakkındaki değerlendirme hukuki nitelikte olduğundan davaya bakan hâkimin CMK madde 63 ve 6754 sayılı Bilirkişilik Kanunu madde 3/3'te hükmü kapsamında uzman bilirkişilere başvurularak sonucuna göre karar vermesi uygun bir hareket tarzı olacaktır. ${ }^{23}$

\section{B. KORUNAN HUKUKİ DEĞER}

FSEK madde 71 ile eser sahibinin manevi, mali ve bunlarla bağlantılı hakları korunmakta ve himaye altına alınmış olmaktadır. ${ }^{24}$ Gerçekten, eser sahibinin eseri üzerinde; eserini kamuya arz, adının belirtilmesi, eserde değişiklik yapılmasından menetme, eseri üzerinde mutlak şekilde tasarrufta bulunabilme yetkisi gibi yetkileri haizdir. Bahse konu manevi haklar, eser sahibinin şahsına sıkı sıkıya bağlı, devredilemeyen, vazgeçilemeyen, miras yoluyla mirasçlara intikal etmeyen, herhangi bir tasarrufun caiz olmadığı haklardır. ${ }^{25}$ Ayrıca; işleme, çoğaltma, yayma ve temsil hakları da eser sahibinin mali hakları olarak FSEK'te tanınmıştır.

Eser sahibinin bilim dünyasına bir eser kazandırmış olması ile maddi kazanç, itibar, şöhret, eser ortaya çıkarmanın verdiği haz duygusu, şeref gibi bir takım manevi ve ulvi duygular söz konusu olmaktadır. ${ }^{26}$ İşte FSEK madde 71'de çeşitli suçlar ve cezalar ihdas olunarak eser sahibinin bahsettiğimiz hem maddi hem de manevi kazançları hukuki koruma altına alınmış olmaktadır. Eser sahibinin maddi ve manevi haklarından bağımsız olarak anılan hükümlerle bilim camiasının etik ilkeleri, akademik dürüstlük, bilim etiği ve kamunun bilim çevresine olan güveni koruma altına alındığını söylemek yanlış olmayacaktır.

23 6754 sayılı Bilirkişilik Kanunu madde 3/3: “Genel bilgi veya tecrübeyle ya da hâkimlik mesleğinin gerektirdiği hukuki bilgiyle çözümlenmesi mümkün olan konularda bilirkişiye başvurulamaz"; Yargitay HGK, 2017/63 E., 2019/86 K.

24 "Açıtır ki, ister tam, ister kısmi nitelikte olsun, intihalin (aşırmanın, çalıntının) varlığı hâlinde, buna maruz kalan hak sahibi, hukukun kendisine tanıdiğı yasal yollara başvurma hakkına sahiptir. Zira intihal, hak sahibinin mali ve manevi haklarının ihlali anlamı taşımaktadır." (Yargitay HGK, 2017/63 E., 2019/86 K.)

25 YAZICIOĞLU, R. Yılmaz, Fikri Mülkiyet Hukukundan Kaynaklanan Suçlar, On İki Levha Yayıncılık, İstanbul, 2009, s. 180.

26 YAMAN, Dilara, "Fikir ve Sanat Eserleri Kanunu'nda Düzenlenen Bir Eserden Kaynak Göstermeksizin İktibasta Bulunma Suçu (m. 71/1-III)" Dokuz Eylül Üniversitesi Hukuk Fakültesi Dergisi, C. 12, 2010. s.1559. 


\section{SUÇUN UNSURLARI}

\section{Suçun Maddi Unsurları}

\section{a. Fail}

Kanun metninden intihal suçunda fail bakımından herhangi bir özelleştirilmeye gidilmediği için failin herhangi bir kimse olabileceğini söyleyebiliriz. FSEK madde 71/2, 3 ve 5 fıkralarındaki suçlar açısından başkasına ait esere, kendi eseri olarak ad koyan, bir eserden kaynak göstermeksizin iktibasta bulunan ve bir eserle ilgili olarak yetersiz, yanlış veya aldatıcı mahiyette kaynak gösteren kişi faildir. Öte yandan Basın Kanunu madde 11'deki ; "Süreli yayınlar ve süresiz yayınlar yoluyla işlenen suçlardan eser sahibi sorumludur." hükmü de bu nevi suçlarda failin tespiti bakımından önemlidir.

\section{b. Mağdur}

İntihal suçunun mağduru failin hareketleri sonucunda yani kendi eserine başkasının ismi konulan, kaynak göstermeksizin eserinden iktibasta bulunulan, eseriyle ilgili olarak yetersiz, yanlış veya aldatıcı mahiyette kaynak gösterilen eser sahibidir. ${ }^{27}$ Eser sahibi ise FSEK madde 8'e göre, "eseri meydana getiren kişi"dir. ${ }^{28}$ Eser sahipliği, kanundan kaynaklanan malî ve manevi hakların öznesi olma, eserinden istifade etme, eserinden başkalarının izinsiz yararlanmasını men etme ve malî ve manevi haklar üzerinde tasarrufta bulunma yetkisine sahip olmayı ifade eden bir terimdir. ${ }^{29}$

Sadece gerçek kişiler eser sahibi olabileceklerinden suçun mağduru olabilirler. Tüzel kişilere devredilen bir hak söz konusu ise bunlar da suçtan zarar gören sıfatıyla açllan davaya katılabilirler. ${ }^{30}$

27 Doktrinde intihal suçunun mağdurunun bizatihi eser sahibi olduğundan bahisle intihal suçunun özgü suç mahiyetinde olduğu savunulmuştur. (YAZICIOĞLU, s. 259.)

28 Eser sahipliğinin maddi bir fiille kazanıldığı için, bir fikri ürün meydana getiren gerçek kişinin tasarruf ehliyetinin bulunup bulunmadığının önem taşımadığı, dolayısıyla küçükler, kısıtlılar veya ayırt etme gücü bulunmayanların da eser sahibi olabilme yetkisini haiz oldukları ifade edilmiştir. (ATEŞ, Mustafa, Fikri Hukukta Eser, Turhan Kitabevi, Ankara, 2007, s. 12.)

29 YILMAZTEKİN, s. 501.

30 BAYINDIR, Sinan, “Eser Sahibinin İzni Olmaksızın Eseri Umuma İletim Suçu”, TBB Dergisi, 2014 (113) s.318. 
Mağdur birden fazla olabilir. Birden çok yazarlı bir kitabın suçun konusu olması bu kabildendir. Nitekim FSEK madde 9 ve 10' da da eser sahiplerinin birden fazla oluşu düzenlenmiştir. ${ }^{31}$ Dolayısıyla birden fazla yazarın birlikte vücuda getirdikleri eser kısımlara ayrılabiliyorsa ve her bir yazarın eserin hangi parçasının sahibi olduğu anlaşılabiliyorsa mağdur da buna göre belirlenir.

\section{c. Suçun Konusu}

İntihal suçlarının konusu failin kaynak göstermeden faydalandığı, kendisine ait olmadığı halde haksız olarak kendi ismini yazar olarak gösterdiği veyahut kendi eserini oluştururken faydalanmış olduğu eser hakkında yanlış veya aldatıcı mahiyette kaynak gösterdiği eserdir. ${ }^{32}$ Eserin tanımı FSEK madde 1/B de yapılmıştır. Kanun'a göre eser; "sahibinin hususiyetini taşıyan ve ilim ve edebiyat, musiki, güzel sanatlar veya sinema eserleri olarak sayılan her nevi fikir ve sanat mahsulleri"ni, eser sahibi ise; "eseri

31 "II - Eser sahiplerinin birden fazla oluşu:

Madde 9 - Birden fazla kimselerin birlikte vücuda getirdikleri eserin kısımlara ayrlması mümkünse, bunlardan her biri vücuda getirdiği kısmın sahibi sayılır. Aksi kararlaştırllmış olmadıkça, eseri birlikte vücuda getirenlerden her biri bütün eserin değişstirilmesi veya yayımlanması için diğerlerinin iştirakini istiyebilir. Diğer taraf muhik bir sebep olmaksızın iştirak etmezse, mahkemece müsaade verilebilir. Aynı hüküm mali hakların kullanılmasında da uygulanır.

III - Eser sahipleri arasındaki birlik:

Madde 10 - Birden fazla kimsenin iştirakiyle vücuda getirilen eser ayrllmaz bir bütün teşkil ediyorsa, eserin sahibi, onu vücuda getirenlerin birliğidir. Birliğe adi şirket hakkındaki hükümler uygulanır. Eser sahiplerinden biri, birlikte yapılacak bir muameleye muhik bir sebep olmaksızın müsaade etmezse, bu müsaade mahkemece verilebilir. Eser sahiplerinden her biri, birlik menfaatlerine tecavüz edildiği takdirde tek başına hareket edebilir.

Bir eserin vücuda getirilmesinde yapılan teknik hizmetler veya teferruata ait yardımlar, iştirake esas teşkil etmez.

(Ek: 21/2/2001 - 4630/6 md.) Birden fazla kimsenin iştiraki ile vücuda getirilen eser, ayrılmaz bir bütün teşkil ediyorsa bir sözleşmede veya hizmet şartlarında veya eser meydana getirildiğinde yürürlükte olan herhangi bir yasada aksi öngörülmediği takdirde birlikte eser üzerindeki haklar eser sahiplerini bir araya getiren gerçek veya tüzel kişi tarafindan kullanilır. Sinema eseri ile ilgili haklar saklıdır."

32 "Intihalden bahsedebilmek için her şeyden önce kıyaslamaya konu fikri ürünlerin FSEK anlamında eser olması gerekmektedir. FSEK'e göre eser, sahibinin hususiyetini taşıyan ve ilim ve edebiyat, musiki, güzel sanatlar veya sinema eserleri olarak sayllan her nevi fikir ve sanat mahsulleridir. Başka bir deyişle, bir fikri ürünün eser olarak kabul edilebilmesi için sahibinin hususiyetini taşıması ve kanunda sınırlı sayıda belirtilmiş olan eser türlerinden birine dâhil edilebilmesi koşulları bulunmalıdır." (Yargıtay HGK, 2017/63 E., 2019/86 K.) 
meydana getiren kişi"yi ifade eder. Aynı Kanun'un "Ilim ve Edebiyat Eserleri" başlıklı 2. maddesine göre; "herhangi bir şekilde dil ve yazı ile ifade olunan eserler ve her biçim altında ifade edilen bilgisayar programlar ve bir sonraki aşamada program sonucu doğurması koşuluyla bunların hazırlık tasarımları ..." eser olarak kabul edilmektedir.

FSEK'te çok geniş bir eser yelpazesine yer verildiği görülmektedir. FSEK, ilim ve edebiyat eserlerinin haricinde musiki eserleri, sinema eserleri, işlenmeler ve derlemeleri de eser sayarak bu ürünleri de koruma altına almıştır. Burada önemli olan eserin sahibinin hususiyetini taşıması ve fikir-sanat mahsulü olmasıdır. Yine madde metninden eserin sözlü veya yazılı olabileceği, herhangi bir şekil şartına tabi olmadığı da anlaşılmaktadır. Yargıtay'a göre FSEK ile eser sahibine sağlanan hak bizatihi fikrin kendisi olmayıp onun eser sahibince ifade ediliş tarzıdır. ${ }^{33}$

\section{d. Fiil}

FSEK madde 71'de 6 ayrı fikrada (EK 4. madde de eklenirse 7 ayrı fıkra) çeşitli suçlara yer verilmiştir. ${ }^{34}$ Çalışmamızı ilgilendirmesi bakımından biz sadece 2, 3 ve 5. fıkralarda yer verilen suçları ele alacağımızı yukarıda belirtmiştik. Nitekim madde 71'de sayılan suçlardan sadece 2, 3 ve 5. fıkralarda yer alan suçlar salt intihal suçu vasfındadır. Ayrıca TCK

"5846 sayıl Fikir ve Sanat Eserleri Kanunu uyarınca, bir eser korumasından yararlanabilmek için ortaya çıkan eserin mutlaka Kanun'da sayılan eser türlerinden birine girmesi gerektiŏi gibi, ortaya çıan eserlerde ise korunan unsur, eserin arkasındaki duygu ve düşünce olmayıp, o düşüncenin ifade ediliş şeklidir. Herhangi bir ifadenin eser kapsamında korunabilmesi için de eserin tümü ya da koruma talep edilen parçasının FSEK m. 1/B-a uyarmca, sahibinin hususiyetini taşıması gerekmektedir." (Yargıtay 11. HD, 17.7.2017, 2016/9284 E., 2017/4126, K.)

34 "Madde 71 -(Değişik: 23/1/2008-5728/138 md.)

Bu Kanunda koruma altına alınan fikir ve sanat eserleriyle ilgili manevi, mali veya bağlantılı haklart ihlal ederek:

...

2. Başkasına ait esere, kendi eseri olarak ad koyan kişi altı aydan iki yıla kadar hapis veya adlî para cezasıyla cezalandırılır. Bu fiilin dağıtmak veya yayımlamak suretiyle işlenmesi hâlinde, hapis cezasının üst sınırı beş yıl olup, adlî para cezasına hükmolunamaz.

3. Bir eserden kaynak göstermeksizin iktibasta bulunan kişi altı aydan iki yıla kadar hapis veya adlî para cezasıyla cezalandırılır.

...

5. Bir eserle ilgili olarak yetersiz, yanlış veya aldatıcı mahiyette kaynak gösteren kişi, altı aya kadar hapis cezast ile cezalandırılır." 
madde 5 mucibince TCK'nın genel hükümleri cezai hükümler içeren özel kanunlar için de geçerli olduğundan cezai hükümler içeren 5846 sayılı Kanun açısından TCK'nın genel hükümlerinin tatbik olunacağını hatırlatmakta fayda vardir.

\section{i. 2. Fikradaki Suç Açısından}

Maddenin ilk fikrasında suçun maddi unsurunun hareket kısmı failin, "başkasına ait esere, kendi eseri olarak ad koyma"sı olarak formüle edilmiştir. Fıkrada fiilin "dağıtmak veya yayımlamak suretiyle" irtikâp olunması ise suçun nitelikli hali olarak gösterilmiştir.

FSEK madde 15 mucibince esere ad koyma yetkisi bizatihi eser sahibine aittir. Eser sahibi rızası ile bu yetkisini 3. kişilere devredebilir. Böyle bir rıza olmaksızın suç konusu esere başka bir isim koyma eser sahibinin hakkına tecavüz teşkil etmektedir. ${ }^{35}$ Failin başkasına ait esere, kendine ait bir esermiş algısı uyandıracak şekilde ismini yazması "ad koyma" şeklinde belirlenen fiili oluşturmaktadır. ${ }^{36}$

35 YENIDÜNYA, Caner, “5846 Sayılı Fikir ve Sanat Eserleri Kanununda Düzenlenen Manevi ve Mali Haklara Tecavüz Suçları", Erzincan Hukuk Fakültesi Dergisi, C. X, S. 3-4, 2006, s.250.

36 "Davacı vekili, müvekkilinin 2000 yılında Yenidoğanlarda Plexus Brachialisin İncelemesi isimli yüksek lisans tezini tamamladığını, müvekkilinin tesadüfen internette yaptığı taramada, davalı Dr. ....'ın 2005 yılında, .... Üniversitesi Tıp Fakültesinde uzmanlık tezi hazırlandığını, bu tezin adının Plexus Braçhials Yapısı, Varyasyonlar ve Cerrahi Önemi olduğunu gördüğ̈̈nü, davalının bu tezle beyin cerrahisi alanında uzman olmaya hak kazandığını, davalının uzmanlık tezinin kendi tezinin kopyası olduğunu, müvekkilinin ismi ve eseri hiç zikredilmeksizin tezinin içeriği, içindeki resimler ve çizimler tamamen, sadece küçük rötuşlarla ...'ın tezinde kullanıldığını, davalının haksız uzmanlık elde ettiğini, haksız kazanç da să̆ladığını ileri sürerek fazlaya ilişkin hakları saklı kalmak kaydıyla, 40.000,00 TL manevi tazminatın ve şimdilik 1.000,00 TL maddi tazminatın haksız fiilin işlendiği günden itibaren işleyecek faiziyle birlikte davalıdan alınarak müvekkiline verilmesini talep ve dava etmiştir. Daval vekili, müvekkilinin tezini hazırlarken birçok dergi, makale, bu konuda hazırlanmış eski tezler, bilimsel kitaplar ve internet ortamında yaptığ inceleme ve araştırmalardan yararlandığını, bu nedenle iktibas ya da sözde intihal yaptığı ileri sürülen davacının teziyle genel bilgiler bölümünün benzerlik göstermesinin doğal olduğunu, bilgilerin davacıya ait olmadığını, belirtilen kaynaklardan derlenen bilgiler olduğunu savunarak davanın reddini istemiştir. Mahkemece, iddia, savunma, bilirkişi raporu ve tüm dosya kapsamına göre, davactnın tezinin ilim ve edebiyat eseri olduğu, davacı tarafindan yazılan tezdeki metin ve resimlerin, şekillerin çok büyük bir bölümünün aynen alındığı, davacının tezinden alıntı yapıldığının belirtilmediği, kendi görüşü gibi sunulduğu, davacının tezinden alınan kısımlardaki dipnotlarm olduğu gibi davalı tezine aktarıldığı bu hali ile davalı tarafindan intihal eyleminin gerçekleştirildiği, olayın özelliği gereği ispatı zor olduğundan dava tarihi itibariyle yürürlükte 
Öte yandan, başkasına ait esere kendi eseriymiş gibi ad koymanın Yükseköğretim Kurumları Etik Davranış İlkelerine göre; “Bilimsel usullere uygun biçimde gerekli atıfları yapmadan ve kaynak göstermeden başkalarının fikir, veri, eser ve yayınlarını kendisine aitmiş gibi yayımlamak" olduğu ifade edilmiştir. ${ }^{37}$

Madde metninde suçun nitelikli hali olarak yer verilen "dağıtmak veya yayımlamak suretiyle" ibaresinden anlaşılması gereken husus failin eserinin maddi/maddi olmayan aslının veyahut nüshalarının işaret, ses veya görüntü nakline yarayan dijital, telli veya telsiz araçlarla umuma iletmesi, kişilerin seçtikleri yer ve zamanda erişimine imkân sağlanmasıdır (FSEK madde 7, 25). Gerçekten de, madde 14'e göre umuma iletim hakkı eser sahibinin eser üzerindeki manevi haklarından bir tanesidir ve bir eserin umuma arz edilip edilmeyeceğini, bunun yayımlanma zamanını ve tarzını münhasıran eser sahibi tayin eder. Burada tecavüz olarak belirlenen fiilin umuma iletim olmayıp eser sahibinin manevi haklarından olan umuma arz etme hakkı olduğunu da belirtmekte fayda vardır. Çünkü esere ad koyma ve bunu da yayımlama bir kez yapılabilecek bir eylemdir. Failin bunu defalarca yapma şansı yoktur. Nitekim umuma arz, ancak bir kez gerçekleşebilen ve eser sahibinin iradesi ile eserin ilk defa aleniyete kavuşması demektir. Kanımızca madde metnindeki "dağıtmak veya yayımlamak suretiyle" ibaresinden de eserin ilk defa kamuoyuna tanıtılması kastedilmektedir. ${ }^{38}$

FSEK madde 71/2' de tarif edilen suç "ad koyma" fiili ile ika edildiğinden suç bu anda tamamlanır ve biter. Bu nedenle anılan suç ani,

olan BK hükümleri doğrultusunda talep edilen maddi tazminatın hakkaniyete uygun olduğu, ... Dava dosyası içerisindeki bilgi ve belgelere, mahkeme kararının gerekçesinde dayanılan delillerin tartışılıp, değerlendirilmesinde usul ve yasaya aykırı bir yön bulunmamasına ve haksız eylem sonucu uğranılan zararın kanıtlanamamış olmasına göre, davacı vekilinin tüm temyiz itirazları yerinde değildir. Sonuç: Yukarıda açılanan nedenle davacı vekilinin tüm temyiz itirazlarının reddiyle usul ve kanuna uygun bulunan hükmün ONANMASINA, ... karar verildi." (Yargitay 11. HD, 9.5.2018, Esas 2016/10824 E., 2018/3384 K.)

37 EREL'e göre, başkasına ait bir esere ad koyma suretiyle sahip çıkılması durumunda FSEK madde15/3'e göre tespit davası da açlabilir. (EREL, 2009, s.121) Aksi yönde TEKINALP, 2005, s.294.

38 Aynı yönde BAYINDIR, s.310; Eser sahibi tarafından umuma arz yetkisinin ihlali neticesinde tecavüzün kaldırılması davası ile beraber, mali hak ihlali nedeniyle maddi tazminat davası da tecavüz eden faile karşı açılabilir. 
hareketin nasıl yapılacağı belirlenmiş olduğundan bağlı hareketli suç olarak formüle edilmiştir. Öte yandan suçun gerçekleşmesi için herhangi bir zarar mevcudiyeti aranmadığından suç soyut tehlike suçu vasfındadır.

\section{ii. 3. Fıkradaki Suç Açısından}

Maddenin 3. Fıkrasında kaynak göstermeden iktibasta bulunma suç olarak düzenlenmiştir. FSEK madde 35'te düzenlenen iktibas bir eser ya da eser parçasının başka bir eser içerisinde kullanılmasıdır. TDK Sözlügüne göre "iktibas" ödünç alma ve alıntı anlamına gelmektedir.

3. fikradaki suçun maddi unsurunun hareket kısmı failin kendi eserini oluştururken yararlanmış olduğu başka bir yazara ait eserdeki fikri veyahut fikrin ifade ediliş tarzını alması fakat iktibası kendi eserinde göstermekten imtina etmesidir. Başka bir deyişle, yazarın kendi eserini oluştururken fikir aldığ 1 /yararlandığ 1 kaynağ sidir. ${ }^{39}$ Bir başka kaynağı kelimesi kelimesine kopyalamak, birçok kaynaktan faydalanıp kendine ait gibi göstermek, paragraf içindeki anahtar kelimeleri değiştirmek veya gizlemek kaynak göstermeden yapılan iktibas fiilleri arasında gösterilebilir. ${ }^{40}$

İntihal fiili açısından kaynak eserin tamamının veya bir kısmının; bir paragrafının veya bir cümlesinin alınması arasında bir fark yoktur. Kes-yapıştır tekniğiyle, kaynağı olduğu gibi almak, kelimelerin yerini değiştirmek veyahut eş anlamlı kelime kullanarak failin kaynağı kendisine aitmiş gibi göstermesi durumlarında da intihal vardır. ${ }^{41}$

Yapılan iktibasta yararlanılan eserin sahibini belli edecek, ona ulaşılmasını sağlayacak bilgilere yer verilmemişe ya da eserin alındığı mecra gösterilmemişse de somut olayda intihal suçunun varlığından söz edebiliriz.

3. fikradaki suç açısından, fail hareketsiz kalma şeklinde yani ihmalen hareket ederek suçun maddi unsurunun hareket kısmını ika etmektedir. İhmalin söz konusu olabilmesi için faile muayyen bir icraî davranışta

39 HAFIZOĞULLARI, Zeki, "Fikir ve Sanat Eserlerinin Cezai Himayesi”, Ankara Üniversitesi Hukuk Fakültesi Dergisi, C. 48, S. 1, 1999, s.6.

40 ÖZENÇ UÇAK / BİRİNCİ, s.191.

${ }^{41}$ YAVUZDOĞAN, Seçkin, “İdari Yargı Kararlarından Hareketle İntihal”, İnönü Üniversitesi Hukuk Fakültesi Dergisi, C. 8, S. 1, 2017, s.242. 
bulunma yükümlüğünün yüklendiği hallerde bu mükellefiyete uygun davranmaması veyahut failin hukuk düzeni tarafından yapılması emredilen hareketleri yapmaması veya geç yapması mevzu bahis olmalıdır. ${ }^{42}$

Yargitay, intihal fiilinin tespitinde;

- Kaynak eserdeki metin ve resimlerin, şekillerin çok büyük bir bölümünün aynen alınması ve alıntı yapıldığının belirtilmemesi,

- Kaynak eserdeki fikirlerin yazarın kendi görüşü gibi sunulması, dipnotların olduğu gibi aktarılması,

- Kaynak eser ile suç konusu eserin başlıkların aynı olması, aynı kelimeler kullanılarak ifade edilmesi,

- Kaynak eserdeki cümlelerin, cümlelerin akış yapılarının aynı veya büyük ölçüde benzer olması,

- Kaynak eser ve suç konusu eser arasında asgari \%50 oranında benzerlik olması gibi parametrelerden faydalandığı görülmektedir. ${ }^{43}$

42 ÖZGENÇ, İzzet, Türk Ceza Hukuku Genel Hükümler, Seçkin, Ankara, 2015, s. 221.

43 "Katılanlar ... ve ... tarafindan uzun bir araştırma sonucu hazırlanan The Potential Of Remote Sensing for Monitoring Kayisdagi and Its Surroundings (İstanbul) Land Cover Changes and their Effects on Physical Geography Conditions başlıklı tebliğin 22 Mayıs 2006 tarihinde Şanlıurfa'da yapılan 18. Uluslararası Toprak Sempozyumuna sunulduğunu, 2006 yılında sempozyumu düzenleyen kuruluş tarafından hazırlanan bildiri kitabında da yayımlandı̆̆̆ın, sanı̆̆ın kendi bilimsel alanları ile ilgili olmayan bu çalışmayı izinsiz olarak Springer Verlag tarafindan çıkarılan Environ Moint Assess (2008) 140:33-42'de diğer sanık ... ile kendi isimlerini koyarak, büyük ölçüde aynen The Potential Of Remote Sensing for Monitoring Land Cover Changes and their Effects on Physical Geography in the area of Kayisdagi Mountain and its surroundingis (İstanbul) başlığı altında yayımlatmaktan ibaret olayda; sanıklar davalı sıfatı ile İstanbul 4. Fikri ve Sınai Haklar Hukuk Mahkemesinin 2009/64 Esas sayılı dosyasında yargılanmış olup tazminata mahkum edilmişler ve Yerel Mahkemenin kararı Yargıtay 11. Hukuk Dairesinin 27/03/2014 tarih, 2013/17163 Esas, 2014/6008 Karar sayılı kararı ile onanarak kesinleşmiştir. Yerel Mahkemece, İstanbul 4. Fikri ve Sınai Haklar Hukuk Mahkemesinin 2009/64 Esas sayılı dava dosyası içerisinde mevcut bilirkişi raporları karara dayanak yapılmış ve dosya arasına birer suretleri koyulmuştur. Yerel Mahkemenin kararına dayanak yaptığı bilirkişi raporlarından da anlaşıldığı üzere, başlıkların içerik olarak aynı olduğu, aynı kelimeler kullanılarak ifade edildiği, özet kısmındaki cümlelerin birebir aynı olduğu veya çok az değişikliklerin bulunduğu giriş bölümündeki makalelerin amaçlarına ilişkin bölümün aynı olduğu ve ayn kelimelerle ifade edildiği, her iki makalede çalışma alanların sınırlandırmak için kullanılan koordinatlarm birebir ayn olduğu, geri kalan cümlelerin birebir ayn veya büyük ölçüde benzer olduğu, cümlelerin akış yapılarının aynı olduğu, metod bölümünde her iki makalede de yöntemin iki temel aşamada özetlendiği ve aym veya benzer cümleler kullanıldığı, makalenin metod bölümünde kullanılan kısımların büyük ölçüde benzer olduğu, çıkan sonuçlarm özetlendiği tablolarda yüzdelik ve alan değerlerinin ayn olduğu, 
Suçun tekemmülü için bir eserden kaynak göstermeksizin iktibasta bulunma fiili tek başına yeterli olmayıp suç konusu eserin alenileşmesi iktiza etmektedir. Nitekim kişisel alanda yapılan ve FSEK madde 71'deki fiillere vücut veren hareketler alenileşmediği sürece herhangi bir suça vücut vermez.

Bu fikra kapsamında değinilmesi iktiza eden bir başka husus ise esinlenme ve iktibas kavramları arasındaki ayrımdır. Bir eserden izinsiz iktibas yapılması ile bir eserden esinlenilerek başka bir eser yaratma farklı olaylarıdır. Yazarın bir eserden esinlenilerek, kendi üslubu ile başka bir eser oluşturması için ilk eser sahibinin iznine ihtiyaç yoktur. ${ }^{44}$ Nitekim,

teknik olarak birbirinden ayrı yapılmış iki çalışmada çalışma alanlarını birebir aynı seçilmesinin ve uygulama aşamasında aynı parametrelerin tercih edilmesinin ve de sonuçların birebir ayn olmasının mümkün bulunmadığ̆ı, 2005 verileri için de konulan şekil ve sonuç tabloları yönünden de aynı değerlendirmenin yapıldı ̆̆ı, sonuç bölümünde kullanılan cümlelerin de birebir aynı veya büyük ölçüde benzer olduğu, söz konusu yayınların en az \%50 oranında aynı olduğu ve sanığa ait makalelenin daha önce yayınlanan tebliğden intihal edilerek yayınlandiğı tespit edilmiştir. 5728 sayıl Kanun ile değişik 5846 sayılı Kanun'un 71/3. maddesi hükmü "Bir eserden kaynak göstermeksizin iktibasta bulunan kişi altı aydan iki yıla kadar hapis veya adli para cezasıyla cezalandırılır. şeklinde düzenlenmiş olup yapılan açıklamalar neticesinde, sanığın eyleminin 5846 sayılı Kanun'un 71/3. maddesine uyduğu gözetilmeyerek ayn Kanun'un 71/1. maddesi uyarınca mahkumiyet hükmü kurulması suretiyle sanık hakkında fazla ceza tayin edilmesi Kanuna aykır ve sanı müdafiinin temyiz nedenleri bu itibarla yerinde görüldü̈̆̈̈nden, HÜKMÜN ... BOZULMASINA...", (Yargitay 19. CD 2016/7859 E., 2017/7407 K.); "...Intihal, özü itibariyle haksız fiilin fikir ve sanat eserleri hukukuna yanstyan bir görünümüdür. O hâlde iki eser arasında intihal incelemesi yapilırken; sonraki eser sahibinin eyleminin, ilk eser sahibinin mali ve manevi haklarndan en az birisini ihlal edip etmediği; sonraki eserin ilk eserden hareketle oluşturulup oluşturulmadiğgi eserler arasında benzerlik varsa ilk eser sahibinin hususiyetinin sonraki esere aynen geçirilip geçirilmediği ve son olarak da tespit edilen benzerliğin FSEK'in 35. maddesinde belirlenen iktibas serbestisi veya esinlenme kapsamında kalıp kalmadığı hususlarının bir bütün olarak araştırılması gerekmektedir." (Yargitay HGK, 2017/63 E., 2019/86 K.)

"İtihal kavramının yanında ayrıca "iktibas" ve "esinlenme" kavramlarına değinmek yerinde olacaktır. İktibas kavramı da FSEK'te açıkça tanımlanmamış olup, FSEK'nin 35. maddesinin birinci fikrasında dört bent hâlinde düzenlenen hükümlerde başka bir eserden diğer bir esere iktibas yapılabilmesinin esasa ilişkin koşulları, ikinci fikrasında ise madde kapsamında yapılacak bir iktibasın geçerli olması için gereken şekli koşullar düzenlenmiştir. Buna göre iktibas, alenileşmiş bir eserden bazı cümlelerin, paragrafların, motif ve tınıların hatta ezgilerin veya alenileşmiş bir güzel sanat eserinin resimlerinin aynen, kaynak gösterilerek başka bir esere konulmasıdır ... Başka bir deyişle iktibas, üçüncü kişilere, eserden herhangi bir ücret ödemeden ve eser sahibinin izin ve icazetine gerek kalmadan hukuk düzenince öngörülen şartlarla ve objektif iyiniyet kurallarına uygun olarak yararlanma konusunda tanınmış sınırl bir yetkidir. Buna karşılık FSEK'in 35. maddesinde belirlenen iktibas serbestisinin şekle ve esasa 
intihal için aranan temel şart, özgün eser sahibinin hususiyetinin suç konusu esere aynen geçmesi olduğundan bir eserden esinlenip kendi hususiyetini yansıtarak meydana getirilmiş eserlerde intihalden söz edilemez. ${ }^{45}$ Tekinalp'e göre bir eserin sahibinin özelliğini taşıyıp taşımadığının tespiti için yazarın üslubuna bakılması icap eder. Çünkü üslup öznellik ihtiva eder. ${ }^{46} \mathrm{Bu}$ bakımdan somut olayda intihal iddiası söz konusu ise yazarların üsluplarına bakılması ve her iki eser arasında üslup açısından bir karşılaştırma yapılarak sonuca gidilmesi gerekir.

FSEK madde 71/3'te tarif edilen suç, "iktibas" fiili ile ika edildiğinden suç bu anda tamamlanır ve biter. Bu nedenle anılan suç ani, kaynak göstermeden iktibasta fiili ile suç meydana geldiğinden bağlı hareketli olarak formüle edilmiştir. ${ }^{47}$ Öte yandan suçun gerçekleşmesi için herhangi bir zarar mevcudiyeti aranmadığından suç soyut tehlike suçu vasfındadır.

\section{iii. 5. Fıkradaki Suç Açısından}

Maddenin 5. fıkrasında yetersiz, yanlış veya aldatıcı mahiyette kaynak gösterme suçu düzenlenmiştir. Doktrinde yanlış veyahut aldatıcı mahiyette kaynak gösterme fiili yanlış künye vererek kaynağın orijinaline ulaşılma ihtimalini ortadan kaldırmak olarak tarif edilmiştir. ${ }^{48}$ Gerçekten de, "atıf sahteciliği" olarak da ifade edilen bu eylemde fail (çeşitli saiklerle) eserinde kaynak göstermekte ve fakat yapılan atıf aldatıcı veyahut yanlış bilgiler içerdiğinden iktibas/alıntının gerçek kaynağına ulaşma ihtimalini

ilişkin şartlarına uyulmadan yapılması her zaman intihal sonucunu doğuracaktır." (Yarg1tay HGK, 2017/63 E. , 2019/86 K.); "Bir eserden izinsiz iktibas yapılması, eserden esinlenme (ilham alma) ve yararlanma serbestisiyle karıştırlmamalıdır. İktibas bir eserin ol uşturulmasında, bir başka eserin parçalarının alıntı yapılarak eserde aynen ve belirli ölçülerde kullanılmasıdır. Esinlenme ise, bir eserin oluşturulmasında, kendisinden önceki eserlerde ortaya konulan düşüncelerden yararlanılması ve bu fikirlerden yola çıkılarak yeni eserin biçimlendirilmesidir. Telif koruması, düşüncenin kendisini değil o düşüncenin ifade ediliş şeklini kapsar. Bir düşüncenin ifade edilmiş şeklinin kısmen dahi alınarak bir başka eserde kullanılması halinde artık esinlenmeden değil, ifadenin kullanılmasından söz edilir." (Yargitay 11. HD, 27.02.2017, 2015/13399 E., 2017/1106 K.) TEKINALP, Ünal, Fikri Mülkiyet Hukuku, Arıkan Yayıncılık, Aralık 2005, s. 147. TEKINALP, s. 99.

47 YAZICIOĞLU, s. 260.

48 ÖZENÇ UÇAK/BİRİNCİ, s.192. 
ortadan kaldırmakta veyahut gerçekte olmayan bir kaynağı varmış gibi göstermektedir. ${ }^{49}$

FSEK madde $71 / 5$ 'te tarif edilen suç "yetersiz, yanlış veya aldatıcı mahiyette kaynak gösterme" fiili ile ika edildiğinden suç anılan hareketin ortaya çıkmasıyla bu anda tamamlanır ve biter. Bu nedenle anılan suç ani, hareketin nasıl yapılacağı belirlenmiş olduğundan bağlı hareketli olarak formüle edilmiştir. Öte yandan suçun gerçekleşmesi için herhangi bir zarar mevcudiyeti aranmadığından bu suç soyut tehlike suçu vasfındadır.

\section{Manevi Unsur}

İntihal suçu taksirle irtikap olunamaz. Kanun koyucu bu suçlar için manevi unsur olarak genel kast aramıştır. Fail başkasına ait esere kendi adını koyarken eserin başkasına ait olduğunu bilmeli ve buna rağmen kendi ismini koyma isteğiyle hareket etmelidir.

Bir eserden kaynak göstermeksizin iktibasta bulunma suçu bak1mından ise failin kastı eserindeki iktibas edilen kısımların başkasına ait olduğunu bilmesi ve anılan fikri kendisininmiş gibi kamuoyuna sunmayı istemesidir.

Yetersiz, yanlış veya aldatıcı mahiyette kaynak gösterme suçunda ise failin iktibas edilen kısımlara ilişkin olarak yapılan atıfların gerçeğe aykırı olduğunu bilmesi ve bu şekilde atıf yapmayı istemesi gerekir. Bu suçların olası kastla da işlenmesi mümkündür. ${ }^{50}$

\section{Hukuka Aykırılık Unsuru}

FSEK'te eser sahibinin rızasının aranmadığı hâllerden birisi olan iktibas serbestisi; "alenileşmiş bir eserin bazı cümle ve fikralarının müstakil bir ilim ve edebiyat eserine alınması ve yayımlanmış diğger eserlerin, maksadın haklı göstereceği bir nispet dahilinde ve içeriğini aydınlatmak maksadıyla bir ilim eserine konulması" olarak tarif edilmiştir.

$49 \quad$ YAZICIOĞLU, s. 257.

50 DEMIRAL BAKIRMAN, Büşra, "İntihal Suçları", Ceza Hukuku ve Kriminoloji Dergisi, C. 3, S. 2, 2015, s.71; Aksi yönde YAZICIOĞLU, s. 262. 
Benzer biçimde herkesin kullanımına açık olan tarihi ve maddi vakıalara ilişkin bilgiler tüm insanlığın malı olup, kimsenin tekelinde değildir ve bunlar telif hakkı ile de korunmamaktadır. ${ }^{51}$

Ayrıca FSEK madde 30 ve devamı maddelerinde kamu düzeni, kamu yararı (örneğin eğitim öğretim amaçlı olarak okullarda kullanma) veya kişisel kullanım amaçlı olarak eser sahibinin izni olmadan söz konusu eserlerin temsili, açılanması bastırılması, çoğaltılması ve yayımlanması serbesttir. Fakat bütün bu hallerde bile olsa eser sahibinin adının zikredilmesi gerekmektedir.

Kanun'da eser sahibinin rızasının aranmadığ 1 diğer bir istisna ise EK madde 11'de sayılmıştır. ${ }^{52}$ Maddeye göre yazılı ilim ve edebiyat

51 “Somut olayda, daval tarafça yayınlanan ... isimle eserin \%14'lük kısmında, davacı tarafindan daha önce yayınlanan çeşitli eserlerden doğrudan veya mealen izinsiz iktibas yoluyla intihal yapıldığı bilirkişi raporlarında zikredilmiş ise de, yukarıda belirtilen ilkeler doğrultusunda, alıntı yapıldı̆̆ı söylenen noktaların, herkesin kullanımına açık olan tarihi ve maddi vakıalara ilişkin bilgiler olup olmadığı, söz konusu bilgilere birçok kaynaktan ulaşıllp ulaşılamayacağı, alıntı yapıldığı söylenen kısımlar yönünden, tarihi ve maddi vakıalar dışında, FSEK 1/B-a kapsamında sahibinin hususiyetini yansitan ve bir eser türü olarak korunan ifadelerin bulunup bulunmadı̆̆ı tartışılmaksızın intihal suretiyle davacı tarafın çoğaltma ve yayma haklarının ihlal edildiği düşüncesinden hareketle davanın kısmen kabulüne karar verilmesi doğru olmamış ve hükmün davalılar yararına bozulmasını gerektirmiştir. Kabule göre de, davacı tarafindan daha önce yayına konulan eserlerin birer tarih kitabı niteliğinde bilimsel eser, daval tarafindan yayina konulan dava konusu ... isimli eserin ise bir edebiyat eseri niteliğinde roman olduğu, davalının eserinin 14. sayfasında, roman yazarken davacinın eserlerinden de yararlandığından bahsetmiş olması karşısında, roman türündeki eserlerde, diğger bilimsel eserlerde olduğu gibi her alıntılamada atıf yapılmasının mutat olup olmadı̆̆̆, bu tür eserlerde eser sahibince olayların seçiliş ve kurgulanışlarının sahibinin hususiyetini de yansitacak şekilde edebi bir dil ve yöntemle aktarılıp aktarılmadığ̆ da dikkate alınarak atıf eşiğinin oldukça düşük tutulmasının gerekip gerekmediği hususunda, aralarında edebiyat ve bilimsel eserlerde ilgili öğretim üyelerinin de olduğu yeni bir bilirkişi heyetinden görüş alınmadan, atıf kurallarına uyulmadı̆̆g gerekçesiyle mahkemece davacının telif haklarının ihlal edildiği sonucuna ulaşılması doğru görülmemiş ve hükmün bu sebeple de davalılar yararına bozulmasını gerektirmiştir." (Yargitay 11. HD., E. 2016/9284, K. 2017/4126, T. 17.7.2017)

"Ek Madde 11- (Ek: 3/3/2004-5101/26 md.) Ders kitapları dahil, alenileşmiş veya yayımlanmış yazll ilim ve edebiyat eserlerinin engelliler için üretilmiş bir nüshası yoksa hiçbir ticarî amaç güdülmeksizin bir engellinin kullanımı için kendisi veya üçüncü bir kişi tek nüsha olarak ya da engellilere yönelik hizmet veren eğitim kurumu, vakıf veya dernek gibi kuruluşlar tarafından ihtiyaç kadar kaset, CD, braill alfabesi ve benzeri formatlarda çoğaltılması veya ödünç verilmesi bu Kanunda öngörülen izinler alınmadan gerçekleştirilebilir. Bu nüshalar hiçbir şekilde satılamaz, ticarete konu edilemez ve amacı dışında kullanılamaz ve kullandırtlamaz. Ayrıca bu nüshalar üzerinde hak sahipleri ile ilgili bilgilerin bulundurulması ve çogaltım amactnon belirtilmesi zorunludur." 
eserlerinden ticari amaçlı olmadan ve engellilerin kullanımı için ihtiyaç kadar çoğaltılması veya ödünç verilmesi, hak sahibine ilişkin bilgilerin bulundurulması şartıyla, serbesttir. ${ }^{53}$

FSEK madde 35/f.-b.1 (ilim ve edebiyat eserlerinde küçük iktibas)'de hangi koşullar altında bir eserden iktibas yapılacağı belirtilmiş olup bu maddelerde belirtilen şartlara uygun şekilde yapılan iktibaslar intihal suçuna vücut vermez. Hukuka uygun bir iktibastan söz edilebilmesi için iktibasın amacın gerektirdiği ölçüde yapılması, kendisine iktibas yapılacak eserin FSEK kapsamında bağımsızlık özelliği taşıması, kendisinden iktibas yapılacak eserin ise alenileşmiş bir eser vasfında olmasıdır. İktibas, kendisinden iktibasta bulunan eserdeki cümle ve fikralar ile sınırlı (küçük iktibas) olup iktibasta kullanılan eserin ve eser sahibinin adından başka ilgili parçanın alındı̆̆ı kısım da gösterilmelidir (kaynak gösterme zorunluluğu). ${ }^{54}$

Hukuka uygun bir iktibastan bahsedilebilmesi için kaynak eser sahibinin hususiyetini/üslubu birebir kopyalanmadan eser sahibi yazar kendi üslubunu/ tarzını/ hususiyetini atıf kurallarına uygun biçimde ortaya koyması icap etmektedir.

Alenileşme için yayımlama şartı aranmaz. Ancak alenileşme eserin umuma arz edilmesi ile mümkündür ve bu eser sahibine ait münhasır bir

53 “...dava konusu fiil, sanığın fiilen sorumlusu olduğu web sitesi aracılığılyla ve gerçek kişi adına gerçekleştirilmiştir. Bu itibarla anılan kullanımın sadece engellilere mahsus tutulduğu kabul edilse dahi bu içeriği (eserleri) erişime sunmak suretiyle gerçekleştirilen içerik sağlayıcllık faaliyeti 5846 sayıl Kanun'un şart koştuğu anlamda "engellilere yönelik hizmet veren eğitim kurumu, vakıf veya dernek gibi kuruluş" tarafindan yürütülen bir faaliyet olmaması nedeniyle istisna kapsamında kabul edilemeyecektir. Diğer taraftan kanun koyucu söz edilen istisnayı sadece "çoğaltma veya ödünç verme" kullanım biçimleriyle ve "ihtiyaç kadar olmak kaydıyla" sinırl tutmuştur. Bu anlamda bir eserin izinsiz olarak bilişim ağları ortamında erişime sunulması Kanun'un 25/2. maddesi anlamında eser sahibinin umuma iletim hakkının ihlal edilmesi anlamına gelecek olup, kanun koyucu engelliler yönünden belirtilen istisna kapsamında eserlerin umuma iletimine imkan tanımamıştır. Bir diğer anlatımla bir eseri bilişim ağları ortamında kişilerin diledikleri yer ve zamanda erişimine sunmanın Kanun'un imkan tanıdığı "ihtiyaç kadar" sınırlaması kapsamında da olamayacă̆ı ve adil (dürüst) kullanım ilkesini ihlal edeceği kuşkusuzdur..."

54 Ancak bilimsel eserlerde caiz olan büyük iktibas eserin tamamının veyahut büyük bir kısmının iktibası demektir. (ÖNCÜ, Özge, “Fikir ve Sanat Eserleri Hukukunda İktibas Serbestîsi ve Sınırları", Doktora Tezi, Dokuz Eylül Üniversitesi Sosyal Bilimler Enstitüsü, İzmir, 2009, s. 182.) 
yetkidir. ${ }^{55}$ FSEK madde 7'ye göre, hak sahibinin rızasıyla umuma arz edilen bir eser alenileşmiş sayılır. Yine hak sahibinin rızasıyla bir eserin aslından çoğaltma ile elde edilen nüshalarının satışa çıkarılması veya dağıtılması ile de o eser yayımlanmış sayılır. Buna göre alenileşme için gerekli olan iki unsur hak sahibinin rızası ve eserin kamuoyunun bilgisine sunulmuş olmasıdır. Eserin alenileşmesi hak sahibinin rızasıyla onun herhangi bir şekilde, söz gelimi basım, internete yükleme, derste anlatma vs. yöntemlerle, umumun bilgisine sunulmasıdır.

\section{SUÇUN ÖZEL GÖRÜNÜŞ ŞEKİLLERİ}

\section{Teşebbüs}

FSEK madde 71'de düzenlenen suçlar hareketin tamamlanması ile oluşacağından bir başka deyişle bu suçlar ani suç olarak formüle edildiğinden bahse konu suçlara teşebbüs caiz değildir. Buna göre, suçun tamamlanmış olması için başkasına ait esere, kendi eseri olarak ad koymak, eseri dağıtmak veya yayımlamak ve bir eserden kaynak göstermeksizin iktibasta bulunmak fiillerinin gerçekleşmiş olması gerekir. Fakat, icra hareketleri bölünebiliyorsa veyahut bu hareketler tek başına ayrı bir suç teşkil ediyorsa hareketin bu kısmı için failin sorumluluğu söz konusu olacaktır.

\section{2. İştirak}

İştirak bakımından genel kurallar geçerlidir. Dolayısıyla iştirakin her hali madde FSEK madde 71' de yer alan suçlar bakımından mümkündür. Suçun kanunî tanımında yer alan fiilleri (başkasına ait esere, kendi eseri olarak ad koymak, eseri dă̆ıtmak veya yayımlamak ve bir eserden kaynak göstermeksizin iktibasta bulunmak) birlikte ika eden kişilerden her birinin müşterek fail olarak sorumluluğu doğacaktır. Başka bir deyişle, anılan suçu birden fazla kişi birlikte irtikâp etmişse bu şahıslardan her birinin müşterek fail olarak cezaî sorumlulukları vardır (TCK madde 37/1). Suçun işlenmesine iştirak eden kişiler suçu birlikte işlemeye karar vermişler (birlikte suç işleme iradesi) ve her bir kişi de ayrı ayrı fiil üzerinde fonksiyonel hakimiyet kurmuş ise bu kişilerden her biri müşterek faildir.

55 ÖNCÜ, s. 76, 115. 
Eserin hangi yazara ait olduğu belli ise ve intihal fiili eserin belli bir kısmıyla sınırlı ise bu durumda iştirak hükümleri söz konusu olmayabilir. Bir editörün koordinesinde çıkarılan bir kitapta bağımsız yazarlardan herhangi birisi intihale başvurmuşsa bu suçtan salt olarak müstakil yazar sorumlu tutulacaktır.

Birden fazla eser sahibinin katkılarının iç içe geçmesiyle meydana gelen ve eserin niteliği bozulmaksızın her bir yazarın katkısının diğerinden ayrılması mümkün olmayan bir eser söz konusu ise iştirak halinde eser sahipliği gündeme gelir. Böyle durumlarda her bir yazar intihal fiilinden birlikte sorumlu olacaktır. Gerçekten de hangi bölümün hangi yazar tarafından yazıldığının tespitinin mümkün olmadığ eserlerde tüm eser sahipleri iştirak halinde sorumlu olurlar (elbirliği halinde eser sahipliği). ${ }^{56}$ Somut olayda elbirliği halinde eser sahipliğinin söz konusu olabilmesi için birden fazla eser sahibi ve her biri bağımsız olarak FSEK kapsamında korunan birden fazla eser söz konusu olmalıdır. Çünkü müşterek eserde, birbirinden bağımsız eserler aynı çatı altında, yani tek bir eser olarak, cisimleşmektedir. ${ }^{57}$ Gerçekten de, iştirak halinde eser sahipliğinde eser sahiplerinden katkısı eserin bütününden ayrı ve bağımsız olarak değerlendirilemez. Tekinalp'e göre iştirak halinde eser sahipliğinden bahsedebilmek için;

- Eserin birden fazla kişi tarafından meydana getirilmesi,

- Eser sahiplerinin her birisinin eserin meydana getirilmesinde esaslı katkısının olması,

- Yazarlarda eseri iştirak halinde meydana getirmeye yönelik iradenin bulunması ve eserin yazarlarının yardımlaşması ile vücuda getirilmiş olmasi,

- Son olarak eser sahiplerinin eserin meydana gelmesindeki katk1larının birbirinden ayrılmasının mümkün olmaması gereklidir. ${ }^{58} \mathrm{Bu}$ durumda iştirak kurallarının uygulanabilmesi için her bir yazarda birlikte suç işleme kararının varlığı ve suç konusu eser üzerinde ortak hâkimiyet kurmuş olup olmadıklarına bakmak icap eder.

\footnotetext{
56 YAVUZDOĞAN, s. 249; YAVUZ/ALICA/MERDIVAN, C. I, s. 208.

57 TEKINALP, 2012, s. 143.

58 YILMAZTEKİN, s. 514, 515.
} 
Suç konusu bir derleme eser (seçme ve toplama eserler) ise eserin yetkili editörü üslubunu ve hususiyetini bu derleme esere yansıtmışsa editör eserin sahibi olarak kabul edileceğinden eserde yer alan intihal eylemlerinden kendisi bizatihi sorumlu olur. Ve fakat derleme eserde müstakil bölümler varsa o bölümü meydana getirenlerin eser sahipliği ve sorumluluğu bulunmaya devam edeceğinden yazarın kendisi intihal fiilinden sorumlu tutulacaktır. ${ }^{59}$

\section{3. İçtima}

Fail eylemi ile madde $71^{\prime}$ de yer alan suçlardan birden fazlasını ika etmişse madde metninde sayılan suçlar aynı suçun seçimlik hareketi olamayıp bağımsız suçlar olduklarından, failin her bir eylemden ayrı ayrı sorumluluğu söz konusu olacaktır. Failin suç konusu eserde hem kaynak göstermeksizin iktibasta bulunmuş olması hem de yetersiz yanıltıcı veyahut aldatıcı mahiyette kaynak göstermesi böyledir.

Somut olayda failin aynı mağdura ait birden fazla eserden kaynak göstermeksizin iktibasta bulunulması söz konusu ise zincirleme suç hükümleri gündeme gelebilir.

Fail, suç konusu eserde farklı yazarlara ait farklı eserlerden kaynak göstermeksizin iktibas yapmış ise, fiil tekliği mevzu bahis olduğundan, aynı neviden fikri içtima kuralları mucibince hakkında hükmolunacak cezanın artırılarak tatbik edilmesi iktiza eder.

\section{E. SORUŞTURMA, KOVUŞTURMA ve YETKİLİ MAHKEME}

Çalışmamızın konusunu oluşturan FSEK madde 71'de 3 ayrı fıkrada sayılan intihal suçları için başkasına ait esere kendi eseri olarak ad koyan kişi altı aydan iki yıla kadar hapis veya adlî para cezasıyla; fiilin dağıtmak veya yayımlamak suretiyle işlenmesi hâlinde, beş yıla kadar hapis cezasıyla; bir eserden kaynak göstermeksizin iktibasta bulunan kişi altı aydan iki yıla kadar hapis veya adlî para cezasıyla; bir eserle ilgili olarak yetersiz, yanlış veya aldatıcı mahiyette kaynak gösteren kişi altı aya kadar hapis cezası belirlenmiştir. Buna göre fail alt sınırı 1 ay (TCK md.49/1) üst sınırı ise 5 yıl olan bir yaptırımla karşı karşıyadır. Anılan cezaların hapis veya adli para cezası olarak birlikte düzenlendiği 
görülmektedir. Buna göre hâkim, faili hapis veya bunun yerine adli para cezası ile cezalandırabilecektir.

Yapılan yargılama sonucuna göre nihai ceza 1 yıl ve daha az süreli olursa, şartları da varsa, sonuç ceza adli para cezası ve diğer seçenek yaptırımlara çevrilebilir (TCK md.50).

Kanun'un "Soruşturma ve Kovuşturma" başlıklı 75. maddesine göre; intihal suçlarından dolayı soruşturma ve kovuşturma yapılması şikâyete bağlıdır. ${ }^{60}$ Maddeye göre şikâyet hakkı eser üzerinde manevi ve malî hak

60 "Dosyanın incelenmesinden; "Relationship Between The Results of Selected Motor Tests and Competitive successfulness in Tennis For Different Age Categories" isimli makale üzerinde manevi ve mali hak sahibi Prof.....'in şikayeti olmadan, şüphelinin 2010 yılında Hirvatistan'da yayımlanan adı geçene ait makaleyi Türkiye'deki bir dergide tekrar yayınladığı, bu makalede araştırıcı isimleri arasında adı yer almamasına ră̆men, bunlar arasına kendi ismini yazdiğı iddialarıyla, .... Hakkında Adnan Menderes Üniversitesince yaptırılan soruşturma sonucunda, şüphelinin lüzum-u muhakemesine karar verildiği anlaşılmıştır. Ancak, şüphelinin atılı suçların takibi şikayete bağlı suçlardan olduğu, eser sahibi sıfatıyla eser üzerindeki manevi hakları tecavüze uğrayan kişinin söz konusu suçlarla ilgili şikayetinin bulunmadığı anlaşıldığından, itirazın kabulüyle Adnan Menderes Üniversitesi Rektörlüğünce oluşturulan Yetkili Kurulun 02/06/2016 tarih ve 2016/8 sayıl lüzum-u muhakeme kararınn bozulmasına, 1'inci ve 2'nci maddelerde atıl suçlar nedeniyle..... hakkında kovuşturmaya yer olmadiğııa..." (Danıştay 1. D, 2016/1430 E., 2016/2035 K.); "5846 sayılı Fikir ve Sanat Eserleri Kanununun 35'inci maddesinde, alenileşmiş bir eserin bazı cümle ve fikralarının müstakil bir ilim ve edebiyat eserine alınması iktibasın belli olacak şekilde yapılması ve iktibas hususunda kullanılan eserin ve eser sahibinin adından başka bir kısmın alındı ̆̆ mesi koşuluyla caiz görüldüğ̈̈, ayn Kanunun 71'inci maddesinin üçüncü bendinde, bir eserden kaynak göstermeksizin iktibasta bulunan kişinin altı aydan iki yıla kadar hapis veya adli para cezast ile cezalandırılacağı, 752 inci maddesinde ise, 71 ve 72 'inci maddede sayılan olduğu, yapılan şikayetin geçerli kabul edilmesi için hak sahiplerinin veya üyesi oldukları meslek birliklerinin hakların kanıtlayan belge ve şair delilleri Cumhuriyet başsavcılı̆̆ına vermeleri gerektiği, bu belge ve delilleri kavuşturmaya yer olmadığı kararı verileceğ i, bu Kanunda yer alan soruşturma ve kovuşturması şikayete bağhı suçlar dolayısıyla başta Milli Eğitim Bakanlığı, Kültür ve Turizm Bakanlığı yetkilileri olmak üzere ilgili gerçek tüzel kişiler tarafindan, eser üzerinde manevi ve mali hak sahibi kişilerin şikayet haklarım kullanabilmelerini sağlamak amacıyla durumdan haberdar edilecekleri hükümlerine yer verilmiştir. Dosyanın incelenmesinden, şüpheliye atılı suçun 5846 sayıl Fikir ve Sanat Eserleri Kanununun 71' inci maddesinin ikinci bendine ilişkin olduğu, söz konusu suçun Dokuz Eylül Üniversitesi Hemşirelik Yüksekokulu Elektronik Dergisinde yayınlanan "Türk Sinemasında Kadının Değişen İmgesi" adlı makalenin yayın tarihi olan 6.4.2012 tarihinde işlendiği, bu suç nedeniyle . tarafindan 27.3.2018 tarihli dilekçeyle Üniversitesine, 2018 Yll için de İzmir Cumhuriyet Başsavcilığına başvurulduğu, takibi şikayete bağhı bu suç için 5237 sayılı Türk Ceza Kanununun 73'üncü maddesinin birinci bendi uyarınca 6 aylık şikayet süresinin geçirilmesi nedeniyle isnat edilen suçla ilgili olarak soruşturma ve kovuşturma yapılamayacağı anlaşıldığından, itirazın kabulüyle Dokuz Eylül Üniversitesi Rektörlüğünce oluşturulan Yetkili 
sahibi kişilere ve hak sahibinin üyesi olduğu meslek birliklerine ait bir haktır. FSEK madde 42/A'ya göre, yetki belgesi veren üyelerinin temsilcisi durumunda olan meslek birlikleri, eser sahiplerinden ve bağlantılı hak sahiplerinden aldıkları yetki belgelerine göre hakların takibini yapma yetkisini haiz olduklarından meslek birliklerinin; icra takibi, dava, karşı dava, temyiz, tahkim ve tenfiz davası bakımından aktif dava ehliyetinin bulunduğu kabul edilmektedir. ${ }^{61}$

Madde metninde eser sahibi yerine hak sahibinden bahsedilmiş olması eser sahibinin mali haklarını devrettiği kişilerin de şikâyet hakkını haiz oldukları anlamına gelmektedir. Fakat münhasıran eser sahibine ait olan manevi haklara tecavüz söz konusu olduğunda şikâyet hakkı sadece eser sahibine aittir. Eser sahibi eser üzerindeki maddi haklarını devretmişse şikâyet hakkı bu hakları devralana geçmiş olmaktadır. Kısmi devir söz konusu ise hem eser sahibinin hem de, kendisine devredilen kısımla sınırlı olarak, devralanın ortak şikâyet hakkı söz konusu olacaktır.

Suç konusu eser birden fazla yazara aitse şikâyet hakkı her bir yazara ait kısım için ilgili yazara aitken (FSEK madde 9); eser yazarlara ait parçalara bölünemiyorsa şikâyet hakkı artık tüm yazarlara aittir (FSEK madde 10).

Şikâyet üzerine Cumhuriyet savcısı suç konusu eşya ile ilgili olarak 5271 sayılı Ceza Muhakemesi Kanunu hükümlerine göre el koyma ve koruma tedbiri uygulayabilir. Cumhuriyet savcısı gerek görmesi hâlinde, suç konusu eserin çoğaltılmasının durdurulmasına karar verebilir. Ancak, bu karar yirmi dört saat içinde hâkimin onayına sunulması iktiza eder (FSEK m. 75/3).

Söz konusu suçlarla ilgili davalar 5235 sayılı Adli Yargı İlk Derece Mahkemeleri ile Bölge Adliye Mahkemelerinin Kuruluş Görev ve Yetkileri Hakkında Kanun'un "Asliye ceza mahkemesinin görevi" başlıklı 11. maddesine göre suçun işlendiği yer asliye ceza mahkemelerin görev alanı içerisindedir.

Kurulan 24.9.2019 tarih ve C.K.K./2019-45 sayıl lüzum-u muhakeme kararnnn bozulmasına, atılı suç nedeniyle ... hakkında kovuşturmaya yer olmadı̆̆ına, .. karar verildi." (Danıştay 1. D, 1106.2020, 2020/520 E., K.); 
5187 sayılı Basın Kanunu madde 11; “Basılmış eserler yoluyla işlenen suç yayım anında oluşur." hükmünü amir olduğundan intihal suçu, suç konusu eserin yayımı anında oluşur. Her ne kadar suçun işlendiği yer, başkasına ait esere, kendi eseri olarak ad koyma, bir eserden kaynak göstermeksizin iktibasta bulunma, bir eserle ilgili olarak yetersiz, yanlış veya aldatıcı mahiyette kaynak gösterme fillerinin irtikap olunduğu yer olarak kabul edilse de yukarıda yaptığımız açıklamalar muvacehesinde suçun işlendiği yer ekseriyetle eserin alenileştiği/yayımlandığı yer olacaktır. Yetkili mahkeme buna göre belirlenir.

Zincirleme suçun söz konusu olduğu durumlarda yetkili mahkeme suçun son işlendiği yer mahkemesi olacaktır.

Fail eseri yurtdışında yayımlamışsa TCK m.14 ve FSEK m. 71 uyarınca Türkiye' de yargılama yapılması (başkasına ait esere kendi eseri olarak ad koyma suçunun nitelikli hali ve bir eserle ilgili olarak yetersiz, yanlış veya aldatıcı mahiyette kaynak gösterme suçu hariç) caiz değildir. ${ }^{62}$

\section{SONUÇ}

Bu çalışmada ilmi ve edebi eserlerde intihal suçu ele alınmıştır. "Bilimsel ya da sanatsal çalışmalarda, bir başkasının ürününün, görüşünün tümünü ya da bir bölümünü kaynak göstermeden kullanma; bilim ve sanat alanında hırsızlık"63 olarak tanımlanan intihali gerçek anlamda ceza hukuku boyutuyla ele alan tek düzenleme 5846 sayılı Fikir ve Sanat Eserleri Kanunu'dur. FSEK madde 71 ile eser sahibinin manevi, mali ve bunlarla bağlantılı hakları, bilim camiasının etik ilkeleri, akademik dürüstlük, bilim etiği ve kamunun bilim çevresine olan güveni himaye ve koruma altına alınmıştır.

FSEK madde 71'deki intihal suçu kapsamında fail herhangi bir kişi olabilirken bu suçun mağduru ise eser sahibidir. Soruşturulması ve kovuşturulması eser sahibinin şikayetine bağlı olan intihal suçu bakımından

62 "Seçimlik cezalarda soruşturma

MADDE 14. - (1) 11 ve 12 nci maddelerde belirtilen hallerde, soruşturma konusu suçun yer aldığı kanun maddesinde hapis cezası ile adli para cezasından birinin uygulanması seçimlik sayılmış ise soruşturma veya kovuşturma açılmaz."

63 TÜBA Türkçe Bilim Terimleri Sözlüğü, http://www.tubaterim.gov.tr/, (E.T.:04.02.2019) 
iktibas serbestisi; herkesin kullanımına açık olan tarihi ve maddi vakıalara ilişkin bilgiler; kamu düzeni, kamu yararı veya kişisel kullanım amaçlı olarak eser sahibinin izni olmadan söz konusu eserlerin temsili, açıklanması bastırılması, çoğaltılması ve yayımlanması ve yazılı ilim ve edebiyat eserlerinden ticari amaçlı olmadan ve engellilerin kullanımı için ihtiyaç kadar çoğaltılması veya ödünç verilmesi hukuka uygunluk nedenleri olarak belirlenmiştir. Anılan suç bakımından teşebbüs genel olarak mümkün değilken iştirak ve içtima açısından ise genel hükümler caridir.

Ülkemizde ve dünyada bilim çevrelerinin önemli etik sorunları arasında intihal bulunmaktadır. Ülkemizde intihalle ilgili olarak yasal düzenlemeler özellikle üniversitelerin yönetmelik ve yönergeleri ile üniversite üst kuruluşlarının mevzuatlarında bulunmaktadır. Fakat öğretim görevinden uzaklaştırmaya sebep olacak kadar ciddi idari yaptırımların söz konusu olduğu bu başlıkta salt bu konuyu düzenleyen bir müktesebat bulunmamaktadır. İdari düzenlemeler ve yaptırımlar söz konusu olsa bile, intihal tespit edilen bir eserde genellikle kıdemsiz ve "arkası olmayan" personel takibata uğrarken kıdemli /referanslı olan hocalara bir işlem yapılmadığı, konunun sümenaltı edildiği görülmektedir.

Çalışmamızda kısaca sebeplerini ve halihazırdaki hukuki durumunu ortaya koymaya çalıştığımız intihal probleminin önüne geçebilmek için öncelikle intihalle mücadele bakımından kurumların politika ve prosedürler belirlemesi, orta öğretimden itibaren öğrencilerin akademik yazım becerilerinin geliştirilmesi, bununla beraber bir bilimsel araştırmanın öncelikle etik olması gerektiği, intihalin etik dışı olduğu, kınanacak bir husus olduğu, bilim insanına yakışmayan emek hırsızlığı olduğu, haksız rekabete yol açtığı, intihale başvurulan durumlarda herhangi bir orijinallik ortaya konulmadığı, bu gayretin havanda su dövmekten farksız olduğu hususlarında farkındalık yaratılması önemlidir. Ayrıca intihalin kamu düzenini, kamu yararını, ilgilendiren boyutu dikkate alındığında tarafsız bir denetleme sisteminin kurulması zorunluluğu ortaya çıkmaktadır. Konunun yasal çalışma boyutunu ilgilendiren tarafı ile beraber bağımsız ve tarafsız iç ve dış denetim ve mer'i hukukun tatbiki caydırıcılığ sağlayacaktır.

FSEK'te intihal suçlarının takibinin şikâyete bağlı olması bizce hatalı bir düzenleme olmuştur. Nitekim, yukarıda da ifade ettiğimiz üzere, 
bahse konu suçlarla sadece eser sahibinin maddi ve manevi hakları değil, akademik dürüstlük, bilim etiği ve kamunun bilim çevresine olan güveni de ihlale uğramaktadır. Bu meyanda FSEK'te yapılacak bir düzenleme ile bu nevi suçların resen soruşturulması gereken bir kamu davası olarak formüle edilmesinin caydırıcılık açısından daha etkin olacağı değerlendirilmektedir. 


\section{KAYNAKLAR}

ATEŞ, Mustafa, Fikri Hukukta Eser, Turhan Kitabevi, Ankara, 2007.

BAYINDIR, Sinan, “Eser Sahibinin İzni Olmaksızın Eseri Umuma İletim Suçu", TBB Dergisi, C. 113, Ankara, 2014, s. 307-338.

BELLİCAN, Cüneyt, “Fikri Hukukta Manevi Haklar ve Manevi Hakların Korunması", Doktora Tezi, İstanbul Kültür Üniversitesi Sosyal Bilimler Enstitüsü, 2008.

DEMIRAL BAKIRMAN, Büşra, "İntihal Suçları”, Ceza Hukuku ve Kriminoloji Dergisi, C.3, S. 2, 2015, s. 57-78.

EREL, N. Şafak, “İlim ve Edebiyat Eserlerinde Çoğaltma ve Yayma Haklarının Kullanılması", İlim ve Edebiyat Eserlerinde Çoğaltma ve Yayama Haklarının İhlali ve Bunun Sonuçları Paneli, 1999, s. 1620.

EREL, N. Şafak, Türk Fikir ve Sanat Hukuku, 3. Bası, Yetkin Yayınları, Ankara, 2009.

GÜCÜKOĞLU, Behlül/AYVAZ REİS, Zerrin, “Türkiye'de ve Dünyada İntihalin Yaptırımları", Akademik Bilişim, XVI. Akademik Bilişim Konferansı Bildirileri, Mersin, 2014, s. 189-197.

HAFIZOĞULLARI, Zeki, "Fikir ve Sanat Eserlerinin Cezai Himayesi", Ankara Üniversitesi Hukuk Fakültesi Dergisi, Cilt 48, Sayı 1, Ankara, 1999, s. 1-14.

ÖNCÜ, Özge, “Fikir ve Sanat Eserleri Hukukunda İktibas Serbestîsi ve Sınırları", Doktora Tezi, Dokuz Eylül Üniversitesi Sosyal Bilimler Enstitüsü, İzmir, 2009.

ÖZENÇ, UÇAK, Nazan/BİRİNCİ, Hatice Gülşen, “Bilimsel Etik ve İntihal", Türk Kütüphaneciliği, C. 22, 2008, s. 187-204.

ÖZGENÇ, İzzet, Türk Ceza Hukuku Genel Hükümler, Seçkin, Ankara, 2015. TEKİNALP, Ünal, Fikri Mülkiyet Hukuku, Arıkan Yayıncılık, 2005.

TEKİNALP, Ünal, Fikri Mülkiyet Hukuku, Vedat Kitapçlık, İstanbul, 2012. TOPRAK, Ziya, “Türkiye' de Akademik Yazı: İntihal ve Özgünlük”, Boğaziçi Üniversitesi Ĕ̆itim Dergisi, C. 34, S. 2, İstanbul, 2017, s. 1-12. 
YAMAN, Dilara, “Fikir ve Sanat Eserleri Kanunu'nda Düzenlenen Bir Eserden Kaynak Göstermeksizin İktibasta Bulunma Suçu (m. 71/1-III)" Dokuz Eylül Üniversitesi Hukuk Fakültesi Dergisi, C. 12, İzmir, 2010, s. 1551-1567.

YAVUZ, Levent/ALICA, Türkay/MERDIVAN, Fethi, Fikir ve Sanat Eserleri Kanunu Yorumu, Cilt I-II, Seçkin Yayınevi, 2. Baskı, Ankara, 2014.

YAVUZDOĞAN, Seçkin, "İdari Yarg1 Kararlarından Hareketle İntihal”, İnönü Üniversitesi Hukuk Fakültesi Dergisi, C. 8, S. 1, 2017, s. 225254.

YAZICIOĞLU, R. Yılmaz, Fikri Mülkiyet Hukukundan Kaynaklanan Suçlar, On İki Levha Yayıncılık, İstanbul, 2009.

YENIDÜNYA, Caner, “5846 Sayılı Fikir ve Sanat Eserleri Kanununda Düzenlenen Manevi ve Mali Haklara Tecavüz Suçları”, Erzincan Hukuk Fakültesi Dergisi, C. X, S. 3-4, 2006, s. 237- 272.

YILMAZTEKİN, Hasan Kadir, "Fikir ve Sanat Eserleri Kanunu Uyarınca Eser Sahipliği ve Hak Sahipliği ile Bunların Tecavüz Davaları Bağlamında Davacı Sıfatına Etkileri", Adalet Dergisi, 2020/2 Sayı 65, s. 499-557.

\section{İnternet Kaynakları:}

Adalet Bakanlığı Hukuk Sözlüğü, http://www.sozluk.adalet.gov.tr/intihal, (E.T.:24.12.2020)

Danıştay Karar Arama Portalı, http://emsal.danistay.uyap.gov.tr/BilgiBankasiIstemciWeb/

https://www.etimolojiturkce.com/arama/intihal, (E.T.:25.10.2020)

Türk Dil Kurumu Sözlüğü, http://www.tdk.gov.tr/index.php?option=com_bts\&view=bts\&kategori1=veritbn\&kelimesec=24523, (E.T.:24.10.2020)

TBMM Mevzuat Bilgi Sistemi, https://mevzuat.tbmm.gov.tr/mevzuat/faces $/$ kanunmaddeleri?pkanunlarno $=54956 \&$ pkanunnumarasi $=57$ 28, (E.T.:05.01.2019)

TBMM Tutanak Dergisi, https://www.tbmm.gov.tr/tutanaklar/TUTAN AK/TBMM/d09/c010/tbmm09010010ss0289.pdf, (E.T.:07.01.2019) 
TÜBA, 2020 Türkiye Bilim Raporu, http://www.tuba.gov.tr/tr/yayinlar/suresiz-yayinlar/raporlar/turkiye-bilim-raporu, (E.T.:29.11.2020)

TÜBA Türkçe Bilim Terimleri Sözlüğü, http://www.tubaterim.gov.tr/, (E.T.:04.02.2019)

Yargitay Karar Arama Portalı, https://karararama.yargitay.gov.tr/YargitayBilgiBankasiIstemciWeb/

Yükseköğretim Kurumları Etik Davranış İlkeleri, http://kurul.odu.edu.tr/files/akademik-etik-ilkeler.pdf, (E.T.:02.01.2019)

Yükseköğretim Kurumları Bilimsel Araştırma ve Yayın Etiği Yönergesi, http://www.yok.gov.tr/web/guest/icerik//journal_cotent/56_INS TANCE_rEHF8BIsfYRx/10279/18187, (E.T.:25.12.2020) 